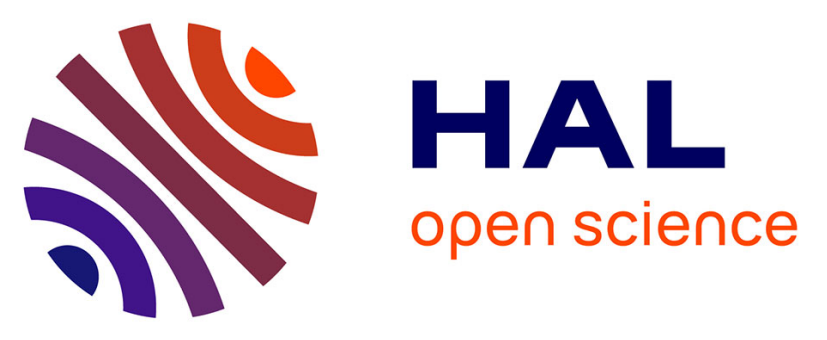

\title{
Gadolinium Complexes of Highly Rigid, Open-Chain Ligands Containing a Cyclobutane Ring in the Backbone: Decreasing Ligand Denticity Might Enhance Kinetic Inertness
}

Oriol Porcar-Tost, Jose Olivares, Agnès Pallier, David Esteban-Gómez, Ona Illa, Carlos Platas-Iglesias, Éva Tóth, Rosa Ortuño

\section{To cite this version:}

Oriol Porcar-Tost, Jose Olivares, Agnès Pallier, David Esteban-Gómez, Ona Illa, et al.. Gadolinium Complexes of Highly Rigid, Open-Chain Ligands Containing a Cyclobutane Ring in the Backbone: Decreasing Ligand Denticity Might Enhance Kinetic Inertness. Inorganic Chemistry, 2019, 58 (19), pp.13170-13183. 10.1021/acs.inorgchem.9b02044 . hal-02358960

\author{
HAL Id: hal-02358960 \\ https://hal.science/hal-02358960
}

Submitted on 18 Nov 2020

HAL is a multi-disciplinary open access archive for the deposit and dissemination of scientific research documents, whether they are published or not. The documents may come from teaching and research institutions in France or abroad, or from public or private research centers.
L'archive ouverte pluridisciplinaire HAL, est destinée au dépôt et à la diffusion de documents scientifiques de niveau recherche, publiés ou non, émanant des établissements d'enseignement et de recherche français ou étrangers, des laboratoires publics ou privés. 


\section{Gadolinium Complexes of Highly Rigid, Open-chain Ligands \\ Containing a Cyclobutane Ring in the Backbone: Decreasing Ligand Denticity Might Enhance Kinetic Inertness}

Oriol Porcar-Tost, ${ }^{1}$ José A. Olivares, ${ }^{1}$ Agnès Pallier, ${ }^{2}$ David Esteban-Gómez, ${ }^{3}$ Ona Illa, ${ }^{1}$ Carlos Platas-Iglesias, ${ }^{* 3}$ Éva Tóth, ${ }^{* 2}$ and Rosa M. Ortuño*1

1: Departament de Química, Universitat Autònoma de Barcelona, 08193 Cerdanyola del Vallès, Barcelona (Spain). E-mail: rosa.ortuno@uab.es (R.M.O.)

2: Centre de Biophysique Moléculaire, UPR 4301, CNRS, Université d'Orléans, rue Charles Sadron, 45071 Orléans Cedex 2 (France). E-mail: eva.jakabtoth@cnrs.fr (É.T.)

3: Centro de Investigacións Científicas Avanzadas (CICA) and Departamento de Química, Universidade da Coruña, Campus da Zapateira-Rúa da Fraga 10, 15008 A Coruña (Spain). Email: carlos.platas.iglesias@udc.es (C.P.-I.) 


\section{ABSTRACT}

In an effort of exploring novel ligand scaffolds for stable and inert lanthanide complexation in MRI contrast agent research, three chiral ligands containing a highly rigid $(1 S, 2 S)$-1,2-cyclobutanediamine spacer and different number of acetate and picolinate groups have been efficiently synthesized. Potentiometric studies show comparable thermodynamic stability for the $\mathrm{Gd}^{3+}$ complexes formed with either the octadentate (L3) $)^{4-}$ bearing two acetate or two picolinate groups or the heptadentate (L2) ${ }^{4-}$ analogue bearing one picolinate and three acetate groups $\left(\log K_{\mathrm{GdL}}=17.41\right.$ and 18.00 for $[\mathrm{Gd}(\mathrm{L} 2)]^{-}$and $[\mathrm{Gd}(\mathrm{L} 3)]^{-}$, respectively). In contrast, their dissociation kinetics reveals to be very different: the monohydrated $[\mathrm{Gd}(\mathrm{L} 3)]^{-}$is considerably more labile, as a result of the significant kinetic activity of the protonated picolinate function, as compared to the bishydrated $[\mathrm{Gd}(\mathrm{L} 2)]^{-}$. This constitutes an uncommon example in which lowering ligand denticity results in a remarkable increase in kinetic inertness. Another interesting observation is that the rigid ligand backbone induces an unusually strong contribution of the spontaneous dissociation to the overall decomplexation process. Thanks to the presence of two inner sphere water molecules, $[\mathrm{Gd}(\mathrm{L} 2)]^{-}$is endowed with high relaxivity $\left(r_{1}=7.9 \mathrm{mM}^{-1} \mathrm{~s}^{-1}\right.$ at $\left.20 \mathrm{MHz}, 25^{\circ} \mathrm{C}\right)$ which is retained in the presence of large excess of endogenous anions, excluding ternary complex formation. The water exchange rate is similar for $[\mathrm{Gd}(\mathrm{L} 3)]^{-}$and $[\mathrm{Gd}(\mathrm{L} 2)]^{-}$, while it is one order of magnitude higher for the trishydrated tetraacetate analogue $[\mathrm{Gd}(\mathrm{L} 1)]^{-}\left(k_{\mathrm{ex}}{ }^{298}=8.1,10\right.$ and $127 \times 10^{6} \mathrm{~s}^{-1}$, respectively). A structural analysis via DFT calculations suggests that the large bite angle imposed by the rigid $(1 S, 2 S)$-1,2-cyclobutanediamine spacer could allow the design of ligands based on this scaffold with suitable properties for the coordination of larger metal ions with biomedical applications.

\section{INTRODUCTION}


Contrast agents (CA) are paramagnetic or superparamagnetic substances that improve the sensitivity and the specificity of magnetic resonance imaging (MRI) examinations. In the last decades, there has been very active research to design more efficient, selective, and safer CAs which are valuable tools in preclinical imaging, clinical diagnosis and more recently in theranostic approaches. ${ }^{1}$ Given its seven unpaired electrons and slow electron spin relaxation, paramagnetic $\mathrm{Gd}^{3+}$ has the greatest effect on nuclear relaxation times of surrounding nuclei and is the most used metal ion in MRI contrast agents. In order to prevent in vivo toxicity of the complexes which would be related to the release of the free, non-complexed metal, $\mathrm{Gd}^{3+}$ needs to be chelated in complexes of high thermodynamic stability and kinetic inertness that ensure stable complexation at physiological $\mathrm{pH}^{2}$ Several mechanisms account for the possible dissociation of $\mathrm{Gd}^{3+}$ complexes. These involve spontaneous and acid-catalyzed processes, as well as dissociation assisted by endogenous metal ions, such as $\mathrm{Zn}^{2+}$ and $\mathrm{Cu}^{2+}$. Typically, complexes formed with macrocyclic ligands are kinetically more inert than the linear analogues, ${ }^{3}$ and their dissociation mechanisms are also different. Whereas the acidcatalyzed pathway is the major contributor to the dissociation of macrocyclic chelates (Chart 1), ${ }^{4}$ linear complexes tend to dissociate via metal-assisted pathways. ${ }^{2 \mathrm{a}, 5}$ For example, transmetallation reactions between [Gd(DTPA-BMA)] and $\mathrm{Cu}^{2+}$ in the presence of citrate, phosphate and bicarbonate anions occur through dissociation of the gadolinium complex assisted by endogenous ligands. ${ }^{5}$ Previous work has shown that the incorporation of rigid moieties in the structure of linear ligands results in significantly improved kinetic inertness of their lanthanide complexes. A remarkable example is the highly rigid $[\mathrm{Gd}(\mathrm{cddadpa})]^{-}$complex (Chart 1). It presents not only good thermodynamic stability but also a kinetic inertness which is unprecedented for a linear ligand, being comparable to those of clinically approved macrocyclic complexes. ${ }^{6}$ 

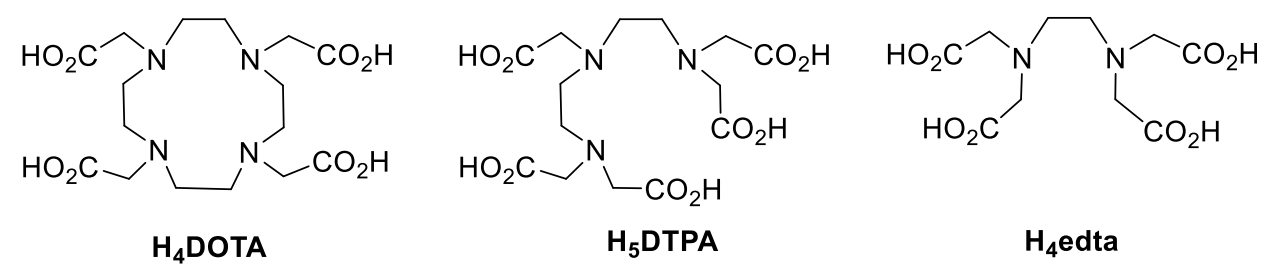<smiles>O=C(O)CN(CC(=O)O)[C@H]1CCCC[C@@H]1N(CC(=O)O)CC(=O)O</smiles>

$\mathrm{H}_{4} \mathrm{cdta}$<smiles>O=C(O)CN(CCN(CC(=O)O)Cc1cccc(C(=O)O)n1)Cc1cccc(C(=O)O)n1</smiles>

$\mathrm{H}_{4}$ octapa<smiles>O=C(O)CN(CC(=O)O)Cc1cccc(CN(CC(=O)O)CC(=O)O)n1</smiles>

$\mathrm{H}_{4} \mathrm{PY}$<smiles>O=C(O)CN(CC(=O)O)[C@H]1CCCC[C@H]1N(CC(=O)O)Cc1cccc(C(=O)O)n1</smiles>

$\mathrm{H}_{4}$ CyPic $3 \mathrm{~A}$<smiles>CN(c1cccc(N(C)N(CC(=O)O)CC(=O)O)n1)N(CC(=O)O)CC(=O)O</smiles>

$\mathrm{H}_{4} \mathrm{HYD}$<smiles>O=C(O)CN(Cc1cccc(C(=O)O)n1)[C@@H]1CCCC[C@H]1N(CC(=O)O)Cc1cccc(C(=O)O)n1</smiles>

$\mathrm{H}_{4}$ cddadpa

Chart 1. Previously reported ligands related to those described and studied in this work

In the design of novel MRI agents, in addition to safety issues, one must also consider the structural parameters which affect the proton relaxivity, $r_{1}$, thus the efficiency of a CA. Indeed, relaxivity is related to a number of microscopic parameters of the paramagnetic chelate as described by the Solomon-Bloembergen-Morgan (SBM) theory of paramagnetic relaxation, ${ }^{7}$ the most important being the number of hydration water molecules $(q)$, the water exchange rate, the rotational dynamics of the complex, and its electron spin relaxation.

Relaxivity is linearly proportional to the number of inner sphere water molecules; however, complexes with high hydration numbers are often thermodynamically less stable, increasing the risk of metal release. Moreover, for bishydrated chelates, the coordinated water molecules can be replaced by endogenous anions thereby decreasing 
the efficiency of the CA. ${ }^{8}$ Usually, complexes with more than one hydration water also present lower kinetic inertness, although it has been observed that the incorporation of cyclohexane or pyridine moieties for instance in $[\mathrm{Gd}(\mathrm{CyPic} 3 \mathrm{~A})]^{-}$or $[\mathrm{Gd}(\mathrm{HYD})]^{-}$, respectively, leads to a remarkable kinetic inertness for these bishydrated complexes, which is comparable to that of the monohydrated [Gd(DTPA) $]^{2-}\left(\right.$ Chart 1). ${ }^{9}$ Furthermore, lowering the ligand basicity for example with hydrazine functions in [Gd(HYD) $]^{-}$, was also identified as an important factor to improve kinetic inertness..$^{9 b}$

In the objective of inducing ligand rigidity, we have incorporated a cyclobutane ring in the scaffold of linear chelators. Here we present the synthesis of three new ligands, $\mathrm{H}_{4}$ cbdta, $\mathrm{H}_{4}$ cbddapa, and $\mathrm{H}_{4}$ cbddadpa that will be referred to as $\mathrm{H}_{4}(\mathrm{~L} 1), \mathrm{H}_{4}(\mathrm{~L} 2)$, and $\mathrm{H}_{4}$ (L3), respectively (Scheme 1; see Experimental Section for full names), and the investigation of their $\mathrm{Gd}^{3+}$ complexes with respect to thermodynamic stability, kinetic inertness and relaxometric properties. In addition to the assessment of the role of a highly rigid ligand backbone, the comparison of complexes $[\mathrm{Gd}(\mathrm{L} 1)]^{-},[\mathrm{Gd}(\mathrm{L} 2)]^{-}$and $\left.[\mathrm{Gd}(\mathrm{L} 3)]^{-}\right)$provides information about the influence of the picolinate moiety and of increasing ligand denticity on these properties. Indeed, (L1) ${ }^{4-},(\mathrm{L} 2)^{4-}$ and (L3) ${ }^{4-}$ are potentially hexa-, hepta- and octadentate, respectively; therefore, coordination of 3,2 and 1 inner sphere water molecules is expected in their $\mathrm{Gd}^{3+}$ complexes. This experimental assessment has been completed with DFT calculations on $[\mathrm{Gd}(\mathrm{L} 2)]^{-}$and $[\mathrm{Gd}(\mathrm{L} 3)]^{-}$in order to gain further insight into the relationship between structure and coordination chemistry of these novel and highly rigid chelators.

\section{RESULTS AND DISCUSSION}


Synthesis of the ligands and of the $\mathbf{G d}^{3+}$ complexes. Ligands $\mathrm{H}_{4}(\mathrm{~L} 1), \mathrm{H}_{4}(\mathrm{~L} 2)$, and $\mathrm{H}_{4}$ (L3) were synthesized according to Scheme 1, starting from chiral and orthogonally protected $(1 S, 2 S)$-1,2-cyclobutanediamine, $\mathbf{1}$, which was previously described. ${ }^{[10]}$

Scheme 1. Synthesis of Ligands H4cbdta, H4cbddapa, and H4cbddadpa ( $\mathrm{H}_{4}\left(\mathrm{LL}_{4}\right)$, $\mathrm{H}_{4}(\mathrm{~L} 2)$, and $\left.\left(\mathrm{H}_{4} \mathrm{L3}\right)\right)$.

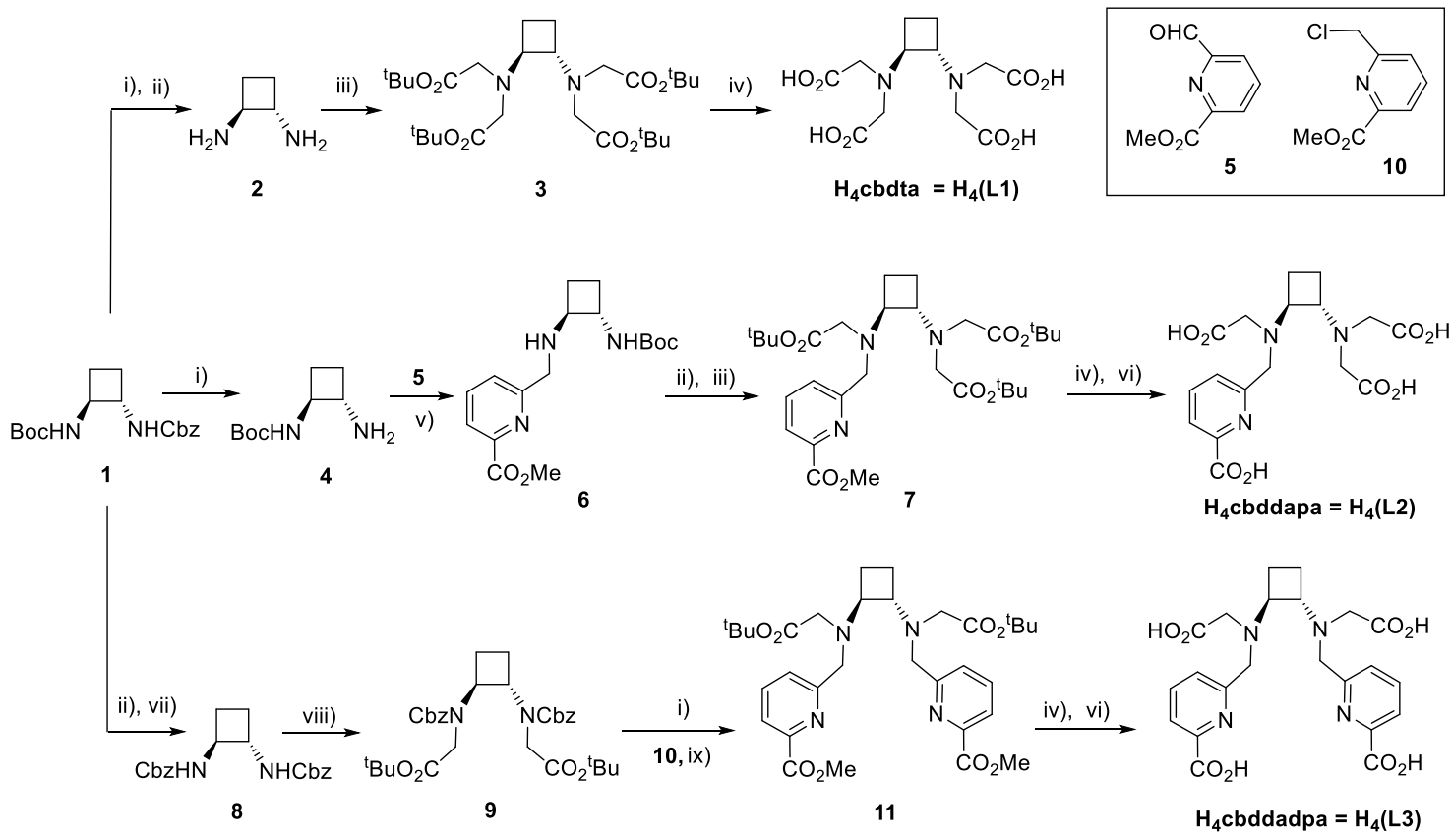

Reagents and conditions: i) $\mathrm{H}_{2}, \mathrm{Pd}(\mathrm{OH})_{2}, \mathrm{CH}_{3} \mathrm{OH}, \mathrm{rt}, 84 \%$; ii) $a$ : $2 \mathrm{M} \mathrm{HCl}$ in diethyl ether, $\mathrm{CH}_{2} \mathrm{Cl}_{2}$, $\mathrm{rt}, 4 \mathrm{~h} ; b: \mathrm{K}_{2} \mathrm{CO}_{3}, \mathrm{CH}_{2} \mathrm{Cl}_{2}$, rt, 2 h, 80\%; iii) tert-butyl bromoacetate, KI, DIPEA, DMF, rt; 18 h, $74 \%$; iv) $4 \mathrm{M} \mathrm{HCl}$ in dioxane, rt, $18 \mathrm{~h}, 77 \%$; v) $a: \mathrm{MeOH}, \mathrm{rt}, 2.5 \mathrm{~h} ; b: \mathrm{NaBH}_{4}, \mathrm{CH}_{3} \mathrm{OH}, 0{ }^{\circ} \mathrm{C}, 2 \mathrm{~h}$, 87\%; vi) $\mathrm{LiOH}, 1: 1$ THF- $\mathrm{H}_{2} \mathrm{O}$, rt, 4 h, quantitative; vii) $\mathrm{ClCO}_{2} \mathrm{Bn}, \mathrm{NaHCO}_{3}, \mathrm{Na}_{2} \mathrm{CO}_{3}, 7: 1 \mathrm{H}_{2} \mathrm{O}-$ acetone, $0{ }^{\circ} \mathrm{C}, 18$ h, 60\%; viii) TBAI, NaH, THF, rt, 18 h, 62\%; ix) KI, DIPEA, DMF, rt, 30 h, $57 \%$.

Sequential deprotection of diamine $\mathbf{1}$ by catalytic hydrogenolysis of the benzyl carbamate and acid hydrolysis of the tert-butyl carbamate afforded free diamine 2 in $64 \%$ yield for the two steps. Alkylation of $\mathbf{2}$ with tert-butyl bromoacetate (4.4 equivalents) in the presence of DIPEA (diisopropylethyl amine) and potassium iodide led to $\mathbf{3}$ that by acidolysis of tert-butyl esters provided $\mathrm{H}_{4}(\mathrm{~L} 1)$ in $54 \%$ yield for the two steps. 
Alternatively, reductive amination of methyl 6-formylpicolinate, 5, with amine 4 gave compound $\mathbf{6}$ in $87 \%$ yield. Subsequent removal of tert-butyl carbamate followed by alkylation led to 7 in $74 \%$ yield. Finally, saponification of the methyl ester with $\mathrm{LiOH}$ followed by acidolysis of the three tert-butyl esters afforded $\mathrm{H}_{4}(\mathrm{~L} 2)$ in $77 \%$ yield.

The synthetic route to $\mathrm{H}_{4}(\mathrm{~L} 3)$ was slightly different since attempts to introduce the second picolinate unit by reductive amination, both in one-pot reaction and in a sequential manner, failed probably due to the severe steric constriction imposed by the cyclobutane ring. Neither the attempt to do it by alkylation of the second amine with methyl chloromethylpicolinate, $\mathbf{1 0}$, was satisfactory. The order of introduction of the substituents by alkylation reactions was then reversed. Symmetric dicarbamate $\mathbf{8}$ was prepared in $60 \%$ yield from 1 by removal of the tert-butyl carbamate and reaction of the free amine with benzyl chloroformate. Compound $\mathbf{8}$ reacted with tert-butyl bromoacetate using $\mathrm{NaH}$ as a base and in the presence of TBAI (tetrabutylammonium iodide) in anhydrous THF for 18 h. Compound 9 was then obtained in $62 \%$ yield. Hydrogenolysis of the benzyl carbamates and subsequent reaction with $\mathbf{1 0}$ lead to $\mathbf{1 1}$ (57\% yield) that, after full deprotection, provided $\mathrm{H}_{4}(\mathrm{~L} 3)$ in $70 \%$ yield.

$[\mathrm{Gd}(\mathrm{L} 1)]^{-},[\mathrm{Gd}(\mathrm{L} 2)]^{-}$, and $[\mathrm{Gd}(\mathrm{L} 3)]^{-}$complexes were synthesized in aqueous solution by reaction of equimolar amounts of the corresponding ligand and $\mathrm{GdCl}_{3} \cdot 6 \mathrm{H}_{2} \mathrm{O}$ followed by adjustment of the $\mathrm{pH}$ to about 7. The HRMS spectra of the complexes showed the expected peaks in each case confirming their formation (see the Supporting Information).

\section{Ligand Protonation Constants and Stability Constants of the Metal Complexes.}

The protonation constants of $(\mathrm{L} 1)^{4-},(\mathrm{L} 2)^{4-}$, and (L3) $)^{4-}$, as well as the stability constants of their complexes with $\mathrm{Gd}^{3+}$ and $\mathrm{Zn}^{2+}$ were determined by $\mathrm{pH}-$ potentiometric titrations. 
For (L3) $)^{4-}$, the stability constants with $\mathrm{La}^{3+}$ and $\mathrm{Lu}^{3+}$ have been also assessed. The global basicity of the three ligands increases in the order (L1) ${ }^{4-}<(L 2)^{4-}<(L 3)^{4-}$ (Table 1), in accordance with the subsequent incorporation of one and two picolinate units, respectively, in $\mathrm{L} 2$ and $\mathrm{L} 3$.

The first protonation constant $\left(\log K_{1}\right)$, corresponding to the protonation of a backbone nitrogen, is similar for (L1) ${ }^{4-}(9.66)$ and (L2) ${ }^{4-}(9.58)$, while it is smaller for $(\mathrm{L} 3)^{4-}(8.89)$. A similar tendency was observed for the tetraacetate edta ${ }^{4-}$ with respect to the bispicolinate derivative octapa ${ }^{4-}$, the latter having a considerably lower $\log K_{1}$ value (8.52 vs. 9.18) ${ }^{2 \mathrm{~h}}$ The rigidity of the ligand also affects the first protonation constant; with identical pending groups, $\log K_{1}$ is typically higher for the rigidified ligands containing a cyclobutyl or a cyclohexyl moiety instead of the flexible ethylene bridge between the two amines (Table 1).

Ligands $(\mathrm{L} 1)^{4-},(\mathrm{L} 2)^{4-}$, and (L3) ${ }^{4-}$ form both non-protonated and monoprotonated mononuclear complexes with $\mathrm{Gd}^{3+}$ and $\mathrm{Zn}^{2+}$ ions. In addition, (L3) ${ }^{4-}$ forms a diprotonated $\mathrm{Zn}^{2+}$ complex as well. These protonated complexes are observed at acidic $\mathrm{pH}$ (see species distribution diagrams in Supporting Information) and can be attributed

Table 1. Protonation Constants of $(\mathrm{L1})^{4-},(\mathrm{L} 2)^{4-},(\mathrm{L3})^{4-}$ and Related Ligands, and Stability Constants of their Metal Complexes $\left(25^{\circ} \mathrm{C}, 0.15 \mathrm{M} \mathrm{KCl}\right)$.

\begin{tabular}{|c|c|c|c|c|c|c|c|}
\hline & $(\mathrm{L} 1)^{4-}$ & $(\mathrm{L} 2)^{4-}$ & $(\mathrm{L} 3)^{4-}$ & edta $^{4-11}$ & cdta $^{4-12}$ & octapa $^{4-} 2^{h}$ & cddadpa $^{4-} 6$ \\
\hline \hline $\log K_{1}{ }^{\mathrm{H}}$ & 9.66 & 9.58 & 8.89 & 9.18 & 9.36 & 8.52 & 9.35 \\
\pm 0.01 & \pm 0.02 & \pm 0.03 & & & & \\
\hline $\log K_{2}{ }^{\mathrm{H}}$ & 5.84 & 6.00 & 6.61 & 6.00 & 5.95 & 5.40 & 5.66 \\
& \pm 0.01 & \pm 0.04 & \pm 0.03 & & & & \\
\hline $\log K_{3}{ }^{\mathrm{H}}$ & 3.06 & 3.78 & 4.26 & 2.58 & 3.62 & 3.65 & 4.20 \\
& \pm 0.02 & \pm 0.04 & \pm 0.06 & & & & \\
\hline
\end{tabular}




\begin{tabular}{|c|c|c|c|c|c|c|c|}
\hline $\log K_{4}{ }^{\mathrm{H}}$ & $\begin{array}{r}2.08 \\
\pm 0.03\end{array}$ & $\begin{array}{r}2.32 \\
\pm 0.05\end{array}$ & $\begin{array}{r}2.97 \\
\pm 0.06\end{array}$ & 2.29 & 2.57 & 2.97 & 3.72 \\
\hline $\log K_{5}^{\mathrm{H}}$ & $\begin{array}{c}1.71 \\
\pm 0.08\end{array}$ & $\begin{array}{r}2.07 \\
\pm 0.05\end{array}$ & $\begin{array}{r}2.79 \\
\pm 0.06\end{array}$ & - & 1.49 & 1.66 & 2.62 \\
\hline$\Sigma \log K_{\mathrm{i}}^{\mathrm{H}}$ & 22.35 & 23.75 & 25.52 & 20.05 & 22.99 & 22.20 & 25.55 \\
\hline $\log K_{\mathrm{GdL}}$ & $\begin{array}{l}14.73 \\
\pm 0.01\end{array}$ & $\begin{array}{l}17.41 \\
\pm 0.01\end{array}$ & $\begin{array}{l}18.00^{\mathrm{b}} \\
\pm 0.02\end{array}$ & 16.28 & 18.97 & 20.23 & 20.68 \\
\hline $\log K_{\mathrm{GdHL}}$ & $\begin{array}{r}2.38 \\
\pm 0.03\end{array}$ & $\begin{array}{r}2.36 \\
\pm 0.02\end{array}$ & $\begin{array}{r}3.28 \\
\pm 0.03\end{array}$ & - & 1.66 & - & 2.38 \\
\hline $\log K_{\mathrm{ZnL}}$ & $\begin{array}{l}12.26 \\
\pm 0.01\end{array}$ & $\begin{array}{r}15.22 \\
\pm 0.01\end{array}$ & $\begin{array}{c}16.28 \\
0.05\end{array}$ & 14.61 & 16.75 & 19.32 & 15.85 \\
\hline $\log K_{\mathrm{ZnHL}}$ & $\begin{array}{r}4.10 \\
\pm 0.01\end{array}$ & $\begin{array}{r}3.78 \\
\pm 0.01\end{array}$ & $\begin{array}{r}4.00 \\
\pm 0.04\end{array}$ & - & 2.57 & - & 3.81 \\
\hline $\log K_{\mathrm{ZnH} 2 \mathrm{~L}}$ & - & - & $\begin{array}{r}3.41 \\
\pm 0.04\end{array}$ & - & - & - & - \\
\hline $\mathrm{pGd}^{a}$ & 13.4 & 16.2 & 17.4 & 15.4 & 18.0 & 20.0 & 19.7 \\
\hline
\end{tabular}

${ }^{a} \mathrm{pGd}=-\log \left[\mathrm{Gd}^{3+}\right.$ free $]$ at $\mathrm{c}_{\mathrm{L}}=10^{-5} \mathrm{M} ; \mathrm{c}_{\mathrm{Gd}}=10^{-6} \mathrm{M} ; \mathrm{pH} 7.4$

${ }^{\mathrm{b}}$ with La: $\log K_{\mathrm{LaL}}=18.74 \pm 0.01$ and $\log K_{\mathrm{LaHL}}=2.8 \pm 0.1$; with $\mathrm{Lu}: \log K_{\mathrm{LuL}}=17.02 \pm 0.01$ and $\log K_{\text {LuHL }}=3.85 \pm 0.1$ 
to the protonation of the carboxylate groups. At $\mathrm{pH} 7$, only the non-protonated complexes exist for any of the three systems. Above $\mathrm{pH} 10$, a slight precipitation was observed in the $[\mathrm{Gd}(\mathrm{L} 1)]^{-}$and $[\mathrm{Gd}(\mathrm{L} 2)]^{-}$samples, possibly due to the formation of hydroxo complexes. The stability constants of those complexes could not be calculated and therefore only experimental data below that point were used to fit the curves and calculate the stability constants.

The stability constants $(\log K)$ of the complexes with $\mathrm{Gd}^{3+}$ and $\mathrm{Zn}^{2+}$ ions follow the same order as their basicity, that is $(\mathrm{L} 3)^{4-}>(\mathrm{L} 2)^{4-}>(\mathrm{L} 1)^{4-}$. This result was expectable owing to the extra coordinating sites provided by the picolinate units with respect to acetates. However, the stability of $[\mathrm{Gd}(\mathrm{L} 3)]^{-}$remains lower than that of the octapa ${ }^{4-}$ and cddadpa $^{4-}$ analogues, suggesting that the cyclobutane ring imposes severe constraint and this prevents the ligand from properly adapting to lanthanide coordination. Nevertheless, the $\mathrm{Gd}^{3+}$ complexes are more stable for each of the three ligands than those of the endogenous $\mathrm{Zn}^{2+}$ cation. This aspect can be important to limit potential $\mathrm{Zn}^{2+}$ transmetallation of the $\mathrm{Gd}^{3+}$ complexes leading to $\mathrm{Gd}^{3+}$ release.

Dissociation kinetic studies. Kinetic inertness of metal complexes is a key parameter for their safe in vivo application. It is usually described by assessing the rate constants of the different pathways that can contribute to the overall dissociation. These involve spontaneous, acid- or metal-catalyzed processes (as depicted in Figure S4 in the Supporting Information), which are characterized by rate constants $k_{0}, k_{1}$ and $k_{2}$, or $k_{3}$, respectively. While macrocyclic chelates are typically endowed with higher kinetic inertness, with rigidified open-chain ligands such as cddadpa ${ }^{6}$ or HYD9 $^{b}$ (Chart 1), kinetic inertness comparable to that of macrocyclic $\mathrm{Gd}^{3+}$ complexes could be achieved.

The kinetic inertness of $[\mathrm{Gd}(\mathrm{L} 2)]^{-}$has been investigated by monitoring the exchange reaction with $\mathrm{Cu}^{2+}$, which is a physiologically relevant metal ion with high efficiency to 
promote transmetalation of $\mathrm{Gd}^{3+}$ complexes in general. The transmetalation was followed by $\mathrm{UV}-\mathrm{V}$ is spectrophotometry in the $\mathrm{pH}$ range 3.5-4.9 at three different $\mathrm{Cu}^{2+}$ concentrations, corresponding to 20,30 and 40-fold excess of the exchanging metal ion (Figure S5 in the Supporting Information). Unfortunately, for [Gd(L3) $]^{-}$even at pH 6.1, the dissociation was too fast to be followed by conventional UV-Vis spectroscopy or relaxometry, thus preventing a quantitative study. Indeed, at $\mathrm{pH} 6.1$ full dissociation was observed at 1 min following the mixing of the $[\mathrm{Gd}(\mathrm{L} 3)]^{-}$complex and 20 equivalents of $\mathrm{Cu}^{2+}$. On the other hand, $[\mathrm{Gd}(\mathrm{L} 1)]^{-}$was not studied in view of its lower stability. For $[\mathrm{Gd}(\mathrm{L} 2)]^{-}$, the pseudo-first-order rate constants, $k_{\mathrm{obs}}$, as a function of the $\mathrm{pH}$ and the $\mathrm{Cu}^{2+}$ ion concentration are shown in Figure 1.

The dissociation is independent of $\mathrm{Cu}^{2+}$ concentration while it is strongly accelerated with decreasing $\mathrm{pH}$, indicating that spontaneous and acid-catalyzed processes are responsible for the dissociation. This is in contrast to the dissociation of [Gd(DTPA) $]^{2-}$ (Chart 1) and some related open-chain complexes where metal-assisted pathways also represent a significant contribution. ${ }^{2 \mathrm{a}}$
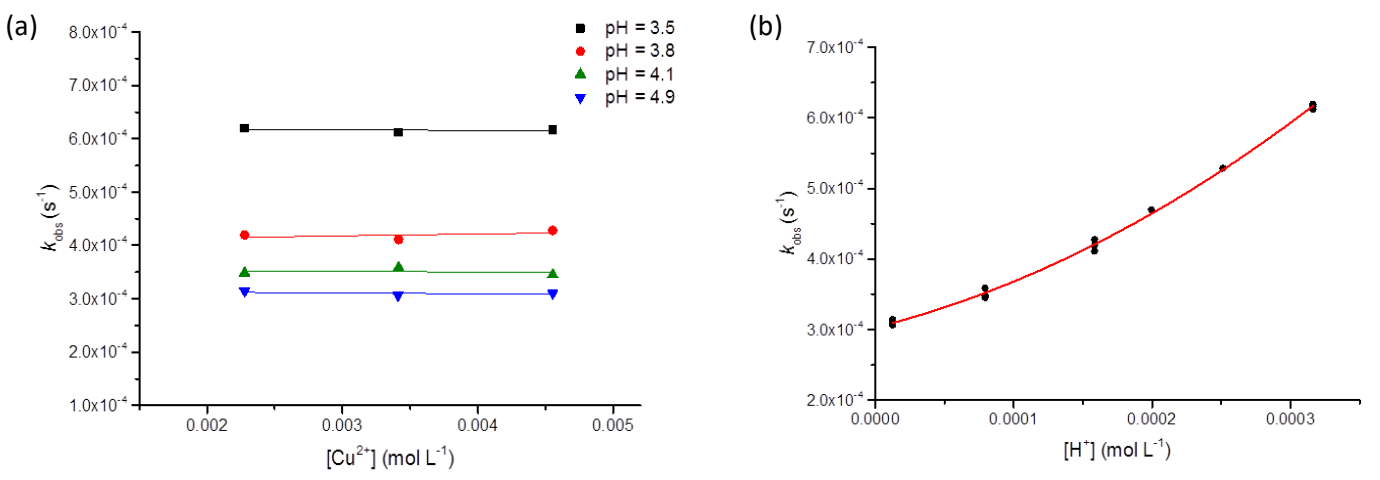

Figure 1. Plot of $k_{\mathrm{obs}}$ values for the dissociation of $[\mathrm{Gd}(\mathrm{L} 2)]^{-}(0.1138 \mathrm{mM})$ as a function of the $\mathrm{Cu}^{2+}$ ion concentration at $\mathrm{pH} 3.5,3.8,4.1$ and 4.9 (a), and as a function of proton concentration (b). The red line on (b) represents the fit to Equation 1. 
The proton concentration dependence of the $k_{o b s}$ values could be fitted to Equation 1, resulting in rate constants $k_{0}, k_{1}$ and $k_{2}$, corresponding to the spontaneous dissociation $\left(k_{0}\right)$ and to the proton catalysed dissociation of the non-protonated $\left(k_{1}\right)$ and the monoprotonated complex $\left(k_{2}\right)$. These rate constants are shown and compared to those of some related complexes in Table 2 .

$$
k_{\mathrm{obs}}=k_{0}+k_{1}\left[\mathrm{H}^{+}\right]+k_{2}\left[\mathrm{H}^{+}\right]^{2} \quad(\text { Equation } 1)
$$

The $k_{1}=0.49 \mathrm{M}^{-1} \mathrm{~s}^{-1}$ value for $[\mathrm{Gd}(\mathrm{L} 2)]^{-}$is similar to $k_{1}$ for the clinically approved MRI agent $[\operatorname{Gd}(D T P A)]^{2-}, 2^{\mathrm{a}}$ and the pyridine-derivatives $\operatorname{GdPY}{ }^{13}$ and $\operatorname{GdHYD}, 9^{\mathrm{b}}$ while it is one order of magnitude higher than that for the cyclohexane-derivative $[\text { Gd(cddadpa) }]^{-}{ }^{6}$ The constant $k_{2}$ is much lower than for [Gd(DTPA) $]^{2-}$, whereas for $[\mathrm{Gd}(\mathrm{cddadpa})]^{-}$, this dissociation pathway was not important at all. When comparing to the pyridine derivatives GdPY and GdHYD, $[\mathrm{Gd}(\mathrm{L} 2)]^{-}$has similar $k_{1}$, but much higher $k_{2}$. In overall, the major difference between $[\mathrm{Gd}(\mathrm{L} 2)]^{-}$and all the other Gd-complexes listed in Table 2 is in the rate constant characterizing the spontaneous dissociation, $k_{0}$. For $[\mathrm{Gd}(\mathrm{L} 2)]^{-}, k_{0}=3 \times 10^{-4} \mathrm{~s}^{-1}$ is higher than the close-to-zero values reported for the other complexes, where $k_{0}$ could be most often neglected in the analysis of the $k_{\mathrm{obs}}$ rate constants.

Table 2. Dissociation Rate Constants of $[\mathrm{Gd}(\mathrm{L} 2)]^{-}$and of Some Relevant $\mathrm{Gd}^{3+}$ Complexes Used as MRI Contrast Agents.

\begin{tabular}{|c|c|c|c|c|c|c|}
\hline ligand & $(\mathrm{L} 2)^{4-}$ & $\mathrm{PY}^{4-13}$ & $\mathrm{HYD}^{4-} 9^{b}$ & octapa $^{4-} 2^{h}$ & cddadpa $^{4-} 6$ & DTPA $^{5-}{ }^{a}$ \\
\hline $\boldsymbol{k}_{\mathbf{0}}\left[\mathrm{s}^{-1}\right]$ & $3.0 \times 10^{-4}$ & - & - & - & - & - \\
\hline $\boldsymbol{k}_{\mathbf{1}}\left[\mathrm{M}^{-1} \mathrm{~s}^{-1}\right]$ & 0.49 & 0.17 & 0.85 & 11.8 & 0.016 & 0.58 \\
\hline
\end{tabular}




\begin{tabular}{|c|c|c|c|c|c|c|}
\hline $\boldsymbol{k}_{2}\left[\mathrm{M}^{-1} \mathrm{~s}^{-1}\right]$ & $1.58 \times 10^{3}$ & 520 & 9.8 & $2.5 \times 10^{4}$ & - & $9.7 \times \cdot 10^{4}$ \\
\hline $\boldsymbol{k}_{3}{ }^{\mathrm{Cu}}\left[\mathrm{M}^{-1} \mathrm{~s}^{-1}\right]$ & - & - & $2.4 \times 10^{-3}$ & 22.5 & $6.8 \times 10^{-4}$ & 0.93 \\
\hline $\boldsymbol{t}_{1 / 2}[\mathrm{~h}]^{a}$ & 0.64 & $2.8 \times 10^{4}$ & $5.3 \times 10^{3}$ & 0.15 & $1.49 \times 10^{5}$ & 202 \\
\hline
\end{tabular}

${ }^{a} t_{1 / 2}=\ln 2 / k_{\mathrm{obs}}$ where $k_{\mathrm{obs}}$ was calculated by using $\mathrm{pH} 7.4$ and $c_{\mathrm{Cu} 2+}=1 \mu \mathrm{M}$.

The dissociation half-life, $t_{1 / 2}$ was calculated using the available rate constants for physiological conditions ( $\mathrm{pH} 7.4$ and $1 \mu \mathrm{M} \mathrm{Cu}^{2+}$ concentration). Among the complexes with a rigidified ligand skeleton containing a pyridine (GdPY, GdHYD) a cyclohexane (Gdcddadpa), or a cyclobutane $\left([\mathrm{Gd}(\mathrm{L} 2)]^{-}\right)$in the ligand backbone, $[\mathrm{Gd}(\mathrm{L} 2)]^{-}$has the shortest $t_{1 / 2}$, thus the lowest kinetic inertness. This is a direct consequence of the importance of the spontaneous dissociation pathway $\left(k_{0}\right)$ probably induced by the presence of the cyclobutane ring, while not present at all for the three other complexes (GdPy, GdHYD and Gdcddadpa) with a rigidified backbone. At $\mathrm{pH}$ 7.4, this spontaneous pathway represents $100 \%$ of the overall dissociation and even at $\mathrm{pH} 4$, the spontaneous pathway is responsible for $80 \%$ of the overall rate. The importance of spontaneous dissociation is very unusual in general for lanthanide poly(amino carboxylate) complexes. This represents an unexpected effect of further increasing the steric constraint in the ligand structure with respect to cyclohexane- or pyridine-derivatives. In addition, the picolinate function also likely contributes to reduce kinetic inertness, though at physiological $\mathrm{pH}$ this effect has no consequence for $[\mathrm{Gd}(\mathrm{L} 2)]^{-}$. Such an influence of the picolinate was previously reported for $[\mathrm{Gd}(\text { octapa })]^{-}$as compared to $[\mathrm{Gd}(\mathrm{edta})]^{-}\left(t_{1 / 2}=\right.$ $0.15 \mathrm{~h} v s 55 \mathrm{~h}$, respectively; $\mathrm{pH} 7.4$ and $1 \mu \mathrm{M} \mathrm{Cu}^{2+}$ ). To explain this difference between $[\mathrm{Gd}(\text { octapa })]^{-}$and $[\mathrm{Gd}(\mathrm{edta})]^{-}$, two factors have been evoked: (a) picolinates increase the rate of the metal-ion-catalyzed dissociation pathway, ${ }^{2 h}$ as a result of their higher denticity which favors the formation of the key dinuclear intermediate, $\mathrm{GdLCu}$, in $\mathrm{Cu}$ - 
assisted dissociation; (b) the protonated picolinate complex has a significant kinetic activity in the decomplexation. For $[\mathrm{Gd}(\mathrm{L} 2)]^{-}$, we could not detect the metal-assisted pathway, but the high kinetic activity of the protonated complex at lower $\mathrm{pH}$ is an important factor, as it is evidenced by the high value of $k_{2}$ (again, this has no effect at $\mathrm{pH}$ 7.4). For the bispicolinate derivative $[\mathrm{Gd}(\mathrm{L} 3)]^{-}$complex, it was impossible to derive dissociation rate constants and analyze the contribution of the individual pathways and estimate the half-life for physiological conditions. One can simply conclude that in this case, the addition of a second picolinate function is detrimental for the kinetic inertness (as experimentally assessed at $\mathrm{pH} 6$ and 4). We should note that a decrease in kinetic inertness upon increasing the ligand denticity has been already reported for linear $\mathrm{Mn}^{2+}$ complexes.(add ref: S. Laine et al, New J. Chem., 2018, 42, 8012-8020.) In general, such a situation can occur when the additional donor atoms of the ligand (i) contribute to more efficient proton-assisted dissociated pathways, since they provide more protonation sites and/or (ii) allow for the formation of dinuclear species, which would not be possible without those donor atoms.

Luminescence studies to assess hydration numbers and anion binding. Inner sphere proton relaxivity is linearly proportional to the number of inner sphere water molecules in the $\mathrm{Gd}^{3+}$ complexes, $q .{ }^{2}$ Hydration numbers have been determined on the corresponding $[\mathrm{Eu}(\mathrm{L} 1)]^{-}, \quad[\mathrm{Eu}(\mathrm{L} 2)]^{-}$and $\quad[\mathrm{Eu}(\mathrm{L} 3)]^{-}$analogues, by measuring luminescence lifetimes in $\mathrm{H}_{2} \mathrm{O}$ and $\mathrm{D}_{2} \mathrm{O}$ solutions (Table 3, see Fig. S7 for the absorption spectra of $\mathrm{L} 2$ and $[\mathrm{Eu}(\mathrm{L} 2)]^{-}$, as well as the emission and excitation spectra of [Eu(L2) $]^{-}$ as an example). ${ }^{14,15}$ All luminescence decay curves were monoexponential (Figure S8). The following empiric equation (Equation 2) is used to calculate $q$ from the differences of luminescence decay lifetime in $\mathrm{H}_{2} \mathrm{O}$ and $\mathrm{D}_{2} \mathrm{O}, \tau_{\mathrm{H} 2 \mathrm{O}}$ and $\tau_{\mathrm{D} 2 \mathrm{O}},\left(A=1.2\right.$ and $B=0.25^{16}$ or $A=1.11$ and $B=0.31){ }^{17}$ 
$q=A\left(\frac{1}{\tau_{H_{2} O}}-\frac{1}{\tau_{D_{2} O}}-B\right) \quad($ Equation 2$)$

Table 3. Luminescence Decay Lifetimes $(\tau)$ and Calculated Hydration Numbers $(q)$. Concentrations of complexes were $0.2 \mathrm{mM}, 0.1 \mathrm{M}$ Hepes buffer, $\mathrm{pH}, \mathrm{pD}=7,25^{\circ} \mathrm{C}$.

\begin{tabular}{|c|c|c|c|c|}
\hline complex & $\tau_{H 2 O}(\mathrm{~ms})$ & $\tau_{D 2 O}(\mathrm{~ms})$ & $q^{a}$ & $q^{b}$ \\
\hline \hline$[\mathrm{Eu}(\mathrm{L} 1)]^{-}$ & 0.241 & 0.760 & 3.1 & 2.8 \\
\hline$[\mathrm{Eu}(\mathrm{L} 2)]^{-}$ & 0.405 & 2.16 & 2.1 & 1.9 \\
\hline$[\mathrm{Eu}(\mathrm{L} 3)]^{-}$ & 0.544 & 1.984 & 1.3 & 1.1 \\
\hline
\end{tabular}

$q$ Values were obtained from: $a$ Equation 2 with $\mathrm{A}=1.2$ and $\mathrm{B}=0.25 . b$ Equation 2 with $\mathrm{A}=1.11$ and $\mathrm{B}=0.31$.

As expected on the basis of ligand denticity, the hydration numbers $(q)$ are 3,2 and 1 for $[\mathrm{Eu}(\mathrm{L} 1)]^{-},[\mathrm{Eu}(\mathrm{L} 2)]^{-}$and $[\mathrm{Eu}(\mathrm{L} 3)]^{-}$, respectively. Figure 2 shows the structures for the three hydrated $\mathrm{Gd}^{3+}$ complexes.

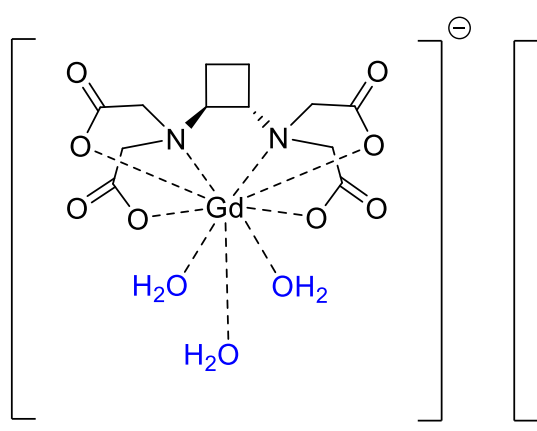

$\left[\mathrm{Gd}(\mathrm{L} 1)\left(\mathrm{H}_{2} \mathrm{O}\right)_{3}\right]^{-}$

$q=3$

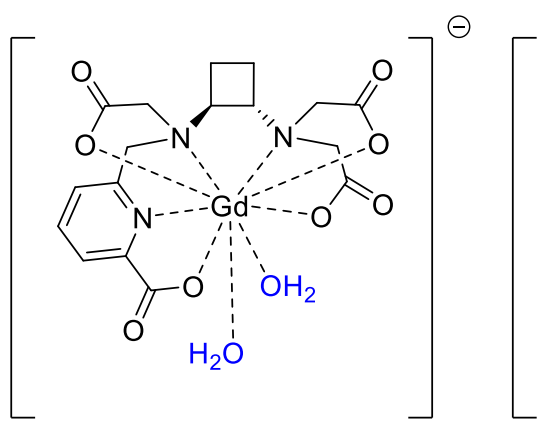

$\left[\mathrm{Gd}(\mathrm{L2})\left(\mathrm{H}_{2} \mathrm{O}\right)_{2}\right]^{-}$

$q=2$

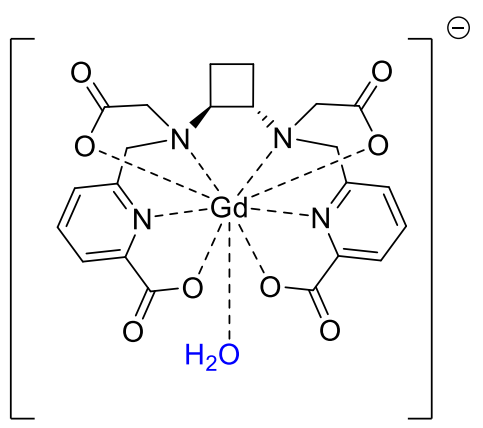

$\left[\mathrm{Gd}(\mathrm{L} 3)\left(\mathrm{H}_{2} \mathrm{O}\right)\right]^{-}$

$q=1$

Figure 2. Structures and $q$ values for $\left[\mathrm{Gd}(\mathrm{L} 1)\left(\mathrm{H}_{2} \mathrm{O}\right)_{3}\right]^{-},\left[\mathrm{Gd}(\mathrm{L} 2)\left(\mathrm{H}_{2} \mathrm{O}\right)_{2}\right]^{-}$, and $\left[\mathrm{Gd}(\mathrm{L} 3)\left(\mathrm{H}_{2} \mathrm{O}\right)\right]^{-}$ complexes. Charges are omitted for clarity. 
Lanthanide chelates containing more than one inner sphere water molecules are often prone to ternary complex formation with endogenous anions, such as carbonate, phosphate or citrate. ${ }^{18,19,20}$ These anions replace the hydration water molecules and lead to a drastic relaxivity decrease of the $\mathrm{Gd}^{3+}$ complexes. ${ }^{21}$ It has been previously shown that for bishydrated complexes, the inner sphere structure and the respective position of the two inner sphere water molecules are primordial to induce or to prevent ternary complex formation. ${ }^{22}$ While GdDO3A easily undergoes ternary complex formation, several bishydrated, linear complexes, such as GdHYD, GdPY, etc, proved to be resistant. ${ }^{23}$

The formation of ternary complexes between $[\mathrm{Gd}(\mathrm{L} 1)]^{-},[\mathrm{Gd}(\mathrm{L} 2)]^{-}$or $[\mathrm{Gd}(\mathrm{L} 3)]^{-}$and carbonate and phosphate, two abundant physiological anions (22-29 and 1.12-1.45 mM concentrations, respectively, in the blood), has been studied by measuring the luminescence lifetime of their related $\mathrm{Eu}^{3+}$ complexes in $\mathrm{H}_{2} \mathrm{O}$ and $\mathrm{D}_{2} \mathrm{O}$. These two anions can interact differently with lanthanide complexes; phosphate has been demonstrated to bind in a monodentate way, while carbonate typically binds in a bidentate manner. The luminescence emission decays of the $\mathrm{Eu}^{3+}$ complexes were recorded in $\mathrm{H}_{2} \mathrm{O}$ and $\mathrm{D}_{2} \mathrm{O}$, in the presence of 10 and 50 equivalents of carbonate and phosphate (50 equivalents are above the physiological concentrations of this anion in human plasma) and the hydration numbers were calculated according to equation 2 (Table 4).

The $q$ values of $[\mathrm{Eu}(\mathrm{L} 2)]^{-}$and $[\mathrm{Eu}(\mathrm{L} 3)]^{-}$did not decrease with the addition of 10 and 50 equivalents of phosphate or carbonate, excluding the formation of ternary $\mathrm{Eu}^{3+}$ complexes with these anions. In contrast, the number of water molecules in $[\mathrm{Eu}(\mathrm{L} 1)]^{-}$ complex decreased by a $22 \%$ when phosphate was added and up to $35 \%$ in the presence of carbonate (Figure S6 in the Supporting Information). These results suggest that stability follows the trend $[\mathrm{Eu}(\mathrm{L} 3)]^{-} \sim[\mathrm{Eu}(\mathrm{L} 2)]^{-}>>[\mathrm{Eu}(\mathrm{L} 1)]^{-}$. Moreover, this tendency is confirmed by the time dependence of the luminescence intensity shown in Fig. S8 
Table 4. $q$ Values for $[\mathrm{Eu}(\mathrm{L} 1)]^{-},[\mathrm{Eu}(\mathrm{L2})]^{-}$and $[\mathrm{Eu}(\mathrm{L3})]^{-}$in the Absence or in the Presence of 10 and 50 Equivalents of Phosphate and Carbonate, respectively. ${ }^{a}$

\begin{tabular}{|c|c|c|c|c|c|}
\hline \multirow{2}{*}{ Complex } & \multirow{2}{*}{$\begin{array}{c}\text { Anion free } \\
{[\mathrm{EuL}]^{-}}\end{array}$} & \multicolumn{2}{|c|}{$q^{a}$} & \multicolumn{2}{c|}{ phosphate } \\
\cline { 3 - 6 } & $10 \mathrm{eq}$ & $50 \mathrm{eq}$ & $10 \mathrm{eq}$ & $50 \mathrm{eq}$ \\
\hline \hline$[\mathrm{Eu}(\mathrm{L} 1)]^{-}$ & 3.1 & 2.4 & 2.4 & 2.0 & 2.1 \\
\hline$[\mathrm{Eu}(\mathrm{L} 2)]^{-}$ & 2.1 & 2.2 & 2.1 & 2.1 & 2.0 \\
\hline$[\mathrm{Eu}(\mathrm{L} 3)]^{-}$ & 1.3 & 1.3 & 1.2 & 1.3 & 1.3 \\
\hline
\end{tabular}

${ }^{a} q$ Values were obtained from Equation 2 with $\mathrm{A}=1.2$ and $\mathrm{B}=0.25 ; 0.2 \mathrm{mM} \mathrm{EuL}, 0.1 \mathrm{M}$ Hepes buffer, $\mathrm{pH}, \mathrm{pD}=7.4,25^{\circ} \mathrm{C}$

DFT calculations. DFT calculations were carried out to gain insight into the relation between molecular structure and the thermodynamic and kinetic properties of $[\mathrm{Gd}(\mathrm{L} 2)]^{-}$ and $[\mathrm{Gd}(\mathrm{L} 3)]^{-}$complexes. On the grounds of previous studies, our calculations included two explicit second-sphere water molecules hydrogen-bonded to each of the coordinated water molecules, while bulk solvent effects were introduced by using a polarized continuum model (PCM). The use of mixed cluster-PCM models is important to achieve a better description of the solution structures of $\mathrm{Gd}^{3+}$ complexes with polyamino polycarboxylate ligands, in particular regarding the $\mathrm{Gd}-\mathrm{O}_{\text {water }}$ distances and the spin density at the $\mathrm{O}$ nuclei of the water molecule. ${ }^{24}$ For the sake of comparison, we also performed DFT calculations on the $\left[\mathrm{Gd}(\text { cddadpa })\left(\mathrm{H}_{2} \mathrm{O}\right)\right]^{-} \cdot 2 \mathrm{H}_{2} \mathrm{O}$ system. The calculated structures of $\left[\mathrm{Gd}(\mathrm{L} 2)\left(\mathrm{H}_{2} \mathrm{O}\right)_{2}\right]^{-} \cdot 4 \mathrm{H}_{2} \mathrm{O}$ and $\left[\mathrm{Gd}(\mathrm{L} 3)\left(\mathrm{H}_{2} \mathrm{O}\right)\right]^{-} \cdot 2 \mathrm{H}_{2} \mathrm{O}$ (Figure 3) show hepta- and octadentate coordination of the ligands to the metal ion, as expected. Our calculations predict rather long Gd-N distances involving the amine nitrogen atoms of the 
ligands, an effect that is more striking in the case of the complex of (L3) ${ }^{4-}$ (Figure 3, Table 5). These Gd-N distances are considerably longer than those calculated for the $\left[\mathrm{Gd}(\text { cddadpa })\left(\mathrm{H}_{2} \mathrm{O}\right)\right]^{-}$complex $(2.81$ and $2.75 \AA)$, reflecting a better accommodation of the $\mathrm{Gd}^{3+}$ ion in the cavity of the latter. This can be attributed to the larger bite angle imposed by the cyclobutanediamine unit, as estimated from the N-Gd-N angles of 69.1 and $65.7^{\circ}$ calculated for the structurally related $\left[\mathrm{Gd}(\mathrm{L} 3)\left(\mathrm{H}_{2} \mathrm{O}\right)\right]^{-}$and $\left[\mathrm{Gd}(\text { cddadpa })\left(\mathrm{H}_{2} \mathrm{O}\right)\right]^{-}$complexes.

The analysis of the electrostatic potential calculated with DFT on isodensity surfaces defined by a 0.001 a. u. contour of the electron density ${ }^{25}$ provide additional valuable information to rationalize the different dissociation kinetic profiles of $\left[\mathrm{Gd}(\mathrm{L} 2)\left(\mathrm{H}_{2} \mathrm{O}\right)\right]^{-}$ and $\left[\mathrm{Gd}(\mathrm{L} 3)\left(\mathrm{H}_{2} \mathrm{O}\right)\right]^{-}$. As for other $\mathrm{Ln}^{3+}$ polyaminocarboxylate complexes, ${ }^{26}$ the surfaces of the complexes present an hydrophilic region containing the carboxylate groups and coordinated water molecules, and a hydrophobic side containing the pyridyl rings and cyclobutane rings. In the $\left[\mathrm{Gd}(\mathrm{L} 3)\left(\mathrm{H}_{2} \mathrm{O}\right)\right]^{-} \cdot 2 \mathrm{H}_{2} \mathrm{O}$ complex, three coordinated carboxylate oxygen atoms are placed in the same region of the complex surface, rendering a more negative electrostatic potential than for the $\left[\mathrm{Gd}(\mathrm{L} 2)\left(\mathrm{H}_{2} \mathrm{O}\right)\right]^{-}$complex $(\mathrm{O} 1, \mathrm{O} 3$ and $\mathrm{O} 4$, Figure 3). This result is in agreement with the higher protonation constant determined with potentiometric measurements for $\left[\mathrm{Gd}(\mathrm{L} 3)\left(\mathrm{H}_{2} \mathrm{O}\right)\right]^{-}\left(K_{\mathrm{GdHL}}=3.28\right)$ compared with $\left[\mathrm{Gd}(\mathrm{L} 2)\left(\mathrm{H}_{2} \mathrm{O}\right)\right]^{-}\left(\log K_{\mathrm{GdHL}}=2.36\right)$. Thus, the much faster complex dissociation of $\left[\mathrm{Gd}(\mathrm{L} 3)\left(\mathrm{H}_{2} \mathrm{O}\right)\right]^{-}$is likely related to the tendency of this complex to protonate, which together with the long Gd-N distances provide a low-energy path for complex dissociation. 

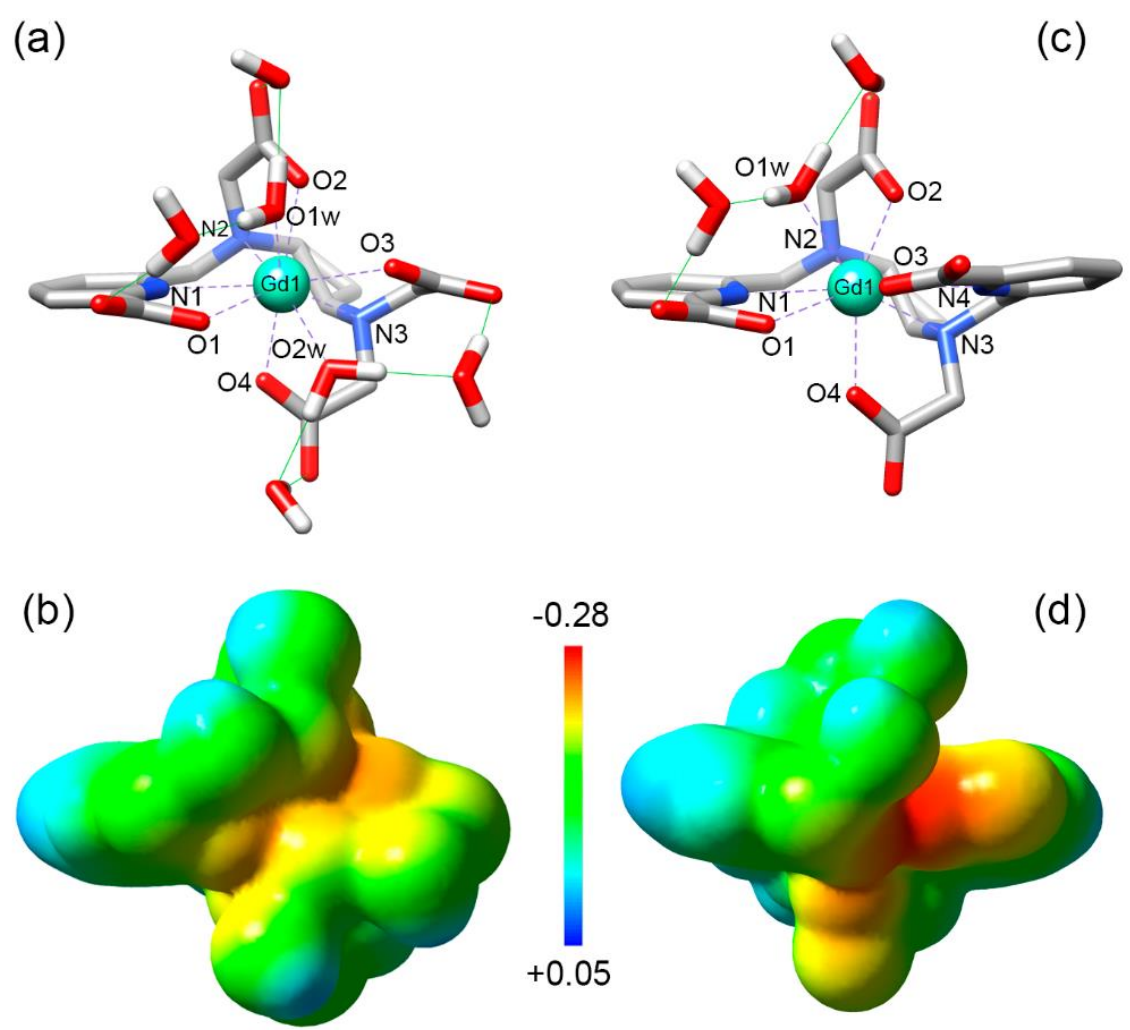

Figure 3. Calculated structure (a) and electrostatic potential (b) of $\left[\mathrm{Gd}(\mathrm{L} 2)\left(\mathrm{H}_{2} \mathrm{O}\right)_{2}\right]^{-} \cdot 4 \mathrm{H}_{2} \mathrm{O}$ and $\left[\mathrm{Gd}(\mathrm{L} 3)\left(\mathrm{H}_{2} \mathrm{O}\right)\right]^{-} \cdot 2 \mathrm{H}_{2} \mathrm{O}(\mathrm{c})$ and (d). Electrostatic potentials (hartree) are mapped on the molecular surfaces defined by the 0.001 electrons $\cdot$ bohr $^{-3}$ contour of the electronic densities.

The two coordinated water molecules in $\left[\mathrm{Gd}(\mathrm{L} 2)\left(\mathrm{H}_{2} \mathrm{O}\right)_{2}\right]^{-} \cdot 4 \mathrm{H}_{2} \mathrm{O}$ present relatively similar calculated Gd-O $\mathrm{O}_{\text {water }}$ distances (2.482 and $2.474 \AA$ A, Figure 3). The ligand wraps around the $\mathrm{Gd}^{3+}$ ion resulting in a set of five donor atoms of the ligand arranged in a relatively planar fashion $(\mathrm{O} 1, \mathrm{O} 3, \mathrm{~N} 1, \mathrm{~N} 2$ and $\mathrm{N} 3)$, with one of the carboxylate ligands containing $\mathrm{O} 2$ and $\mathrm{O} 4$ coordinating above and below this plane, respectively. The two coordinated water molecules approach the metal ion from different sides of the mean plane. As a result, the oxygen atoms of these water molecules define a rather open O-Gd-O angle of $88.4^{\circ}$.

This orientation of the inner-sphere water molecules, together with the negative charge of the complex, are likely responsible for the lack of binding of carbonate and phosphate described above. 
Table 5. Bond Distances of the $\mathrm{Gd}^{3+}$ Coordination Environments $(\AA)$

Obtained with DFT Calculations.

\begin{tabular}{lccc}
\cline { 2 - 4 } & GdL2 & GdL3 & Gdcddadpa \\
\hline Gd1-N1 & 2.744 & 2.785 & 2.599 \\
Gd1-N2 & 2.917 & 3.034 & 2.748 \\
Gd1-N3 & 2.789 & 2.875 & 2.805 \\
Gd1-N4 & - & 2.701 & 2.646 \\
Gd1-O1 & 2.423 & 2.419 & 2.446 \\
Gd1-O2 & 2.389 & 2.390 & 2.394 \\
Gd1-O3 & 2.422 & 2.392 & 2.450 \\
Gd1-O4 & 2.417 & 2.361 & 2.381 \\
Gd1-O1w & 2.482 & 2.519 & 2.570 \\
Gd1-O2w & 2.474 & - & \\
\hline
\end{tabular}

NMRD and ${ }^{17} \mathrm{O}$ NMR studies. According to the Solomon-Bloembergen-Morgan theory of paramagnetic relaxation, the relaxivity is related to a number of microscopic parameters of the paramagnetic chelate, which involve the number of hydration water molecules, the water exchange rate, the rotational dynamics of the complex and its electron spin relaxation. In order to describe these parameters, nuclear magnetic relaxation dispersion (NMRD) profiles have been recorded for $[\mathrm{Gd}(\mathrm{L} 1)]^{-},[\mathrm{Gd}(\mathrm{L} 2)]^{-}$, and $[\mathrm{Gd}(\mathrm{L} 3)]^{-}$complexes in the field range $0.01-80 \mathrm{MHz}$ at 25,37 and $50{ }^{\circ} \mathrm{C}$. The NMRD curves reflect the magnetic field dependency of the proton relaxivity and are helpful to distinguish between different relaxation mechanisms. The profiles of all three complexes (Figure 4) have the shape typical of low molecular weight chelates with a single dispersion between 1 and $10 \mathrm{MHz}$. The relaxivity values decrease with increasing temperature, which is consistent with fast rotation of the complex that limits the 
relaxivity. The relaxivity values measured at $20 \mathrm{MHz}$ and $25^{\circ} \mathrm{C}$ (Table 6 ) are in coherence with the size and the hydration number of the chelates.
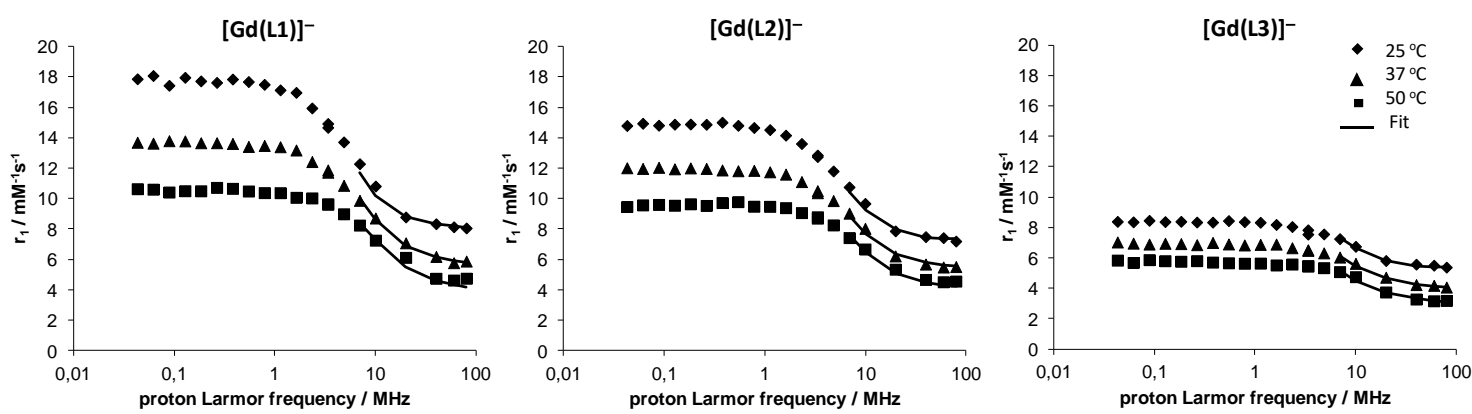

Figure 4. NMRD profiles of $1.88 \mathrm{mM}[\mathrm{Gd}(\mathrm{L} 1)]^{-}, 1.91 \mathrm{mM}[\mathrm{Gd}(\mathrm{L} 2)]^{-}$, and $2.13 \mathrm{mM}[\mathrm{Gd}(\mathrm{L} 3)]^{-}$ in water at $\mathrm{pH}=7$ and temperatures of 25,37 , and $50{ }^{\circ} \mathrm{C}$. Curves represent the simultaneous fit as described in the text.

Table 6. Relaxivity Values, $r_{1}\left(\mathrm{mM}^{-1} \mathrm{~s}^{-1}\right)$, for $[\mathrm{Gd}(\mathrm{L1})]^{-}$, $[\mathrm{Gd}(\mathrm{L2})]^{-}$, and $[\mathrm{Gd}(\mathrm{L3})]^{-}$, and Related $\mathrm{Gd}^{3+}$ Complexes from the Literature, at $25^{\circ} \mathrm{C}$.

\begin{tabular}{|c|c|c|c|c|c|c|}
\hline & {$[\mathrm{Gd}(\mathrm{L} 1)]^{-}$} & {$[\mathrm{Gd}(\mathrm{L} 2)]^{-}$} & {$[\mathrm{Gd}(\mathrm{L} 3)]^{-}$} & {$[\mathrm{Gd}(\mathrm{CyPic} 3 \mathrm{~A})]^{-9^{a}}$} & {$[\mathrm{Gd}(\mathrm{cddadpa})]^{-} 6$} & {$[\mathrm{Gd}(\mathrm{DTPA})]^{-27}$} \\
\hline $\mathrm{r}_{1}{ }^{a}$ & 8.8 & 7.9 & 5.8 & 8.3 & 5.6 & 4.3 \\
\hline $\mathrm{r}_{1}{ }^{b}$ & 8.1 & 7.4 & 5.5 & 7.9 & - & - \\
\hline$q$ & 3 & 2 & 1.2 & 2 & 1 & 1 \\
\hline
\end{tabular}

${ }^{a} 20 \mathrm{MHz}(0.47 \mathrm{~T}) .{ }^{b} 60 \mathrm{MHz}(1.41 \mathrm{~T})$.

Compared with other complexes described in the literature, we can observe that the relaxivity of bishydrated $[\mathrm{Gd}(\mathrm{L} 2)]^{-}$is very similar to that of $[\mathrm{Gd}(\mathrm{CyPic} 3 \mathrm{~A})]^{-}$under the same conditions; identical trend is observed comparing monohydrated complexes $[\mathrm{Gd}(\mathrm{L} 3)]^{-}$and $[\mathrm{Gd}(\mathrm{cddadpa})]^{-}$. Both $[\mathrm{Gd}(\mathrm{L} 2)]^{-}$and $[\mathrm{Gd}(\mathrm{L} 3)]^{-}$present higher values for relaxivity, almost twice that of $[\mathrm{Gd}(\mathrm{DTPA})]^{2-}$ for instance. 
The relaxivities have been also measured in the presence of physiological concentration $(0.6 \mathrm{mM})$ of human serum albumin (HSA) at 20 and $60 \mathrm{MHz}, 37^{\circ} \mathrm{C}$. These values are 30-40\% higher than those recorded in the absence of HSA (see SI), indicating a small protein binding.

The NMRD studies have been complemented by variable temperature ${ }^{17} \mathrm{O}$ transverse relaxation rate and chemical shift measurements which allow, respectively, direct assessment of the water exchange rate and estimation of the hydration number. Figure 5 shows the variable-temperature, reduced transverse ${ }^{17} \mathrm{O}$ relaxation times and chemical shifts for the three gadolinium complexes recorded at $54.2 \mathrm{MHz}(9.4 \mathrm{~T})$. The luminescence lifetime measurements indicated 3,2 and 1 inner sphere water molecule for $[\mathrm{Eu}(\mathrm{L} 1)]^{-},[\mathrm{Eu}(\mathrm{L} 2)]^{-}$, and $[\mathrm{Eu}(\mathrm{L} 3)]^{-}$, respectively, and the ${ }^{17} \mathrm{O}$ chemical shifts measured on the $\mathrm{Gd}^{3+}$ analogues are in accordance with this. Indeed, the scalar coupling constants fitted for the three chelates are around $A / \hbar \sim-3.0-3.1 \times 10^{6} \mathrm{rad} \mathrm{s}^{-1}$, at the lower limit of typical values reported for $\mathrm{Gd}^{3+}$ complexes. DFT calculations performed on the $\left[\mathrm{Gd}(\mathrm{L} 2)\left(\mathrm{H}_{2} \mathrm{O}\right)_{2}\right]^{-} \cdot 4 \mathrm{H}_{2} \mathrm{O}$ and $\left[\mathrm{Gd}(\mathrm{L} 3)\left(\mathrm{H}_{2} \mathrm{O}\right)\right]^{-} \cdot 2 \mathrm{H}_{2} \mathrm{O}$ systems (see computational details below) provide $A / \hbar$ values of $-3.8 \times 10^{6} \mathrm{rad} \mathrm{s}^{-1}$ and $-2.7 \times 10^{6} \mathrm{rad} \mathrm{s}^{-1}$, in reasonable agreement with the experimental data. This also confirms the hydration number of the complexes determined by luminescence lifetime measurements. The $A / \hbar$ determined for $\left[\mathrm{Gd}(\mathrm{L} 3)\left(\mathrm{H}_{2} \mathrm{O}\right)\right]^{-} \cdot 2 \mathrm{H}_{2} \mathrm{O}$ is somewhat higher than those determined for $\left[\mathrm{Gd}(\text { octapa })\left(\mathrm{H}_{2} \mathrm{O}\right)\right]^{-}$using ${ }^{17} \mathrm{O}$ NMR measurements $\left(A / \hbar=-2.3 \times 10^{6} \mathrm{rad} \mathrm{s}^{-1}\right)^{2 \mathrm{i}}$ and DFT calculations $\left(A / \hbar=-2.5 \times 10^{6} \mathrm{rad} \mathrm{s}^{-1}\right) .{ }^{28}$ The relatively low values of $A / \hbar$ determined for these series of complexes might be related to a rather efficient delocalization of the spin density through the aromatic picolinate units. 

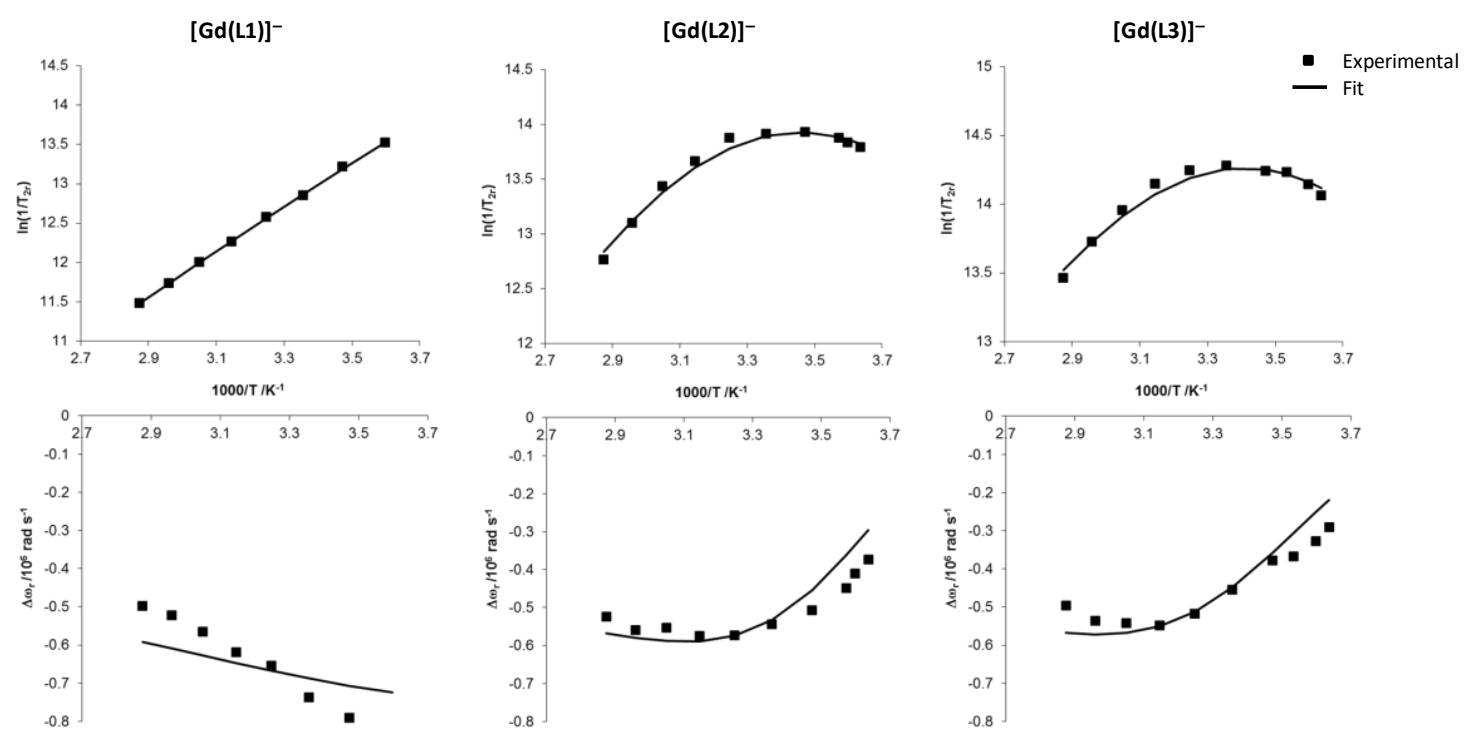

Figure 5. Reduced transverse ${ }^{17} \mathrm{O}$ NMR relaxation rates (top) and ${ }^{17} \mathrm{O}$ NMR chemical shifts (bottom) of the following aqueous solutions: $15.3 \mathrm{mmol} \mathrm{kg}^{-1}[\mathrm{Gd}(\mathrm{L} 1)]^{-}, 14.5 \mathrm{mmol} \mathrm{\textrm {kg } ^ { - 1 }}$ $[\mathrm{Gd}(\mathrm{L} 2)]^{-}$, and $6.46 \mathrm{mmol} \mathrm{kg}^{-1}[\mathrm{Gd}(\mathrm{L} 3)]^{-}$at $\mathrm{pH}=6.5$. Curves represent the simultaneous fit.

The difference in the temperature dependence of the transverse ${ }^{17} \mathrm{O}$ relaxation rates shows that the three complexes have different water exchange rates. While the trishydrated $[\mathrm{Gd}(\mathrm{L} 1)]^{-}$, is in the fast exchange regime in the entire temperature range $\left(1 / \mathrm{T}_{2 \mathrm{r}}\right.$ increases with decreasing temperature), $[\mathrm{Gd}(\mathrm{L} 2)]^{-}$and $[\mathrm{Gd}(\mathrm{L} 3)]^{-}$are in the fast exchange regime at high temperatures and in an intermediate range at lower temperatures. The temperature dependency of the chemical shifts follows the same trend. In the fast exchange region, $1 / \mathrm{T}_{2 \mathrm{r}}$ is determined by the transverse relaxation rate of the coordinated water oxygen, $1 / \mathrm{T}_{2 \mathrm{~m}}$, which is, in turn, influenced by the water exchange rate, $k_{\mathrm{ex}}$, the longitudinal electronic relaxation rate, $1 / \mathrm{T}_{1 \mathrm{e}}$, and the scalar coupling constant, $A / \hbar$.

The reduced transverse ${ }^{17} \mathrm{O}$ relaxation rates and chemical shifts were fitted together with the NMRD profiles according to the SBM theory. The following parameters have been calculated: the water exchange rate, $k_{\mathrm{ex}}{ }^{298}$, the activation enthalpy, $\Delta H^{\ddagger}$, and entropy, $\Delta S^{\ddagger}$, the scalar coupling constant, $A / \hbar$, the rotational correlation time, $\tau_{\mathrm{RH}}$, its activation energy, $E_{\mathrm{r}}$, and the parameters referring to electron spin relaxation, $\Delta^{2}$ and $\tau_{\mathrm{v}}{ }^{298}$. The 
distances between the $\mathrm{Gd}^{3+}$ ion and the protons in the inner and outer coordination sphere were fixed to typical values, $\mathrm{r}_{\mathrm{GdH}}=3.1 \AA$ and $\mathrm{a}_{\mathrm{GdH}}=3.6 \AA$, respectively, and the diffusion coefficient and its activation energy to $D_{\mathrm{GdH}}{ }^{298}=26 \times 10^{-10} \mathrm{~m}^{2} \mathrm{~s}^{-1}$ and $E_{\mathrm{DGdH}}=20 \mathrm{kJmol}^{-1}$. If we are not interested in detailed information about electron spin relaxation, the SBM approach can be applied to the analysis of the NMRD data at medium and high magnetic fields, and gives reliable information on dynamic processes like water exchange and rotational correlation times for small complexes. ${ }^{29}$ Therefore, we included only relaxivity values above $6 \mathrm{MHz}$ in the fitting. The number of water molecules directly coordinated to $\mathrm{Gd}^{3+}, q$, was fixed to 3, 2 and 1 for $[\mathrm{Gd}(\mathrm{L} 1)]^{-},[\mathrm{Gd}(\mathrm{L} 2)]^{-}$and $[\mathrm{Gd}(\mathrm{L} 3)]^{-}$, respectively.

The equations used are given in the ESI and the parameters obtained are shown in Table 7.

While there is a slight increase in the water exchange rate from $[\mathrm{Gd}(\mathrm{L} 3)]^{-}$to $[\mathrm{Gd}(\mathrm{L} 2)]^{-}\left(k_{e x}{ }^{298}=8.1 \times 10^{6} \mathrm{~s}^{-1}\right.$ and $10.0 \times 10^{6} \mathrm{~s}^{-1}$, respectively $),[\mathrm{Gd}(\mathrm{L} 1)]^{-}$has one order of magnitude faster water exchange $\left(k_{e x}^{298}=127 \times 10^{6} \mathrm{~s}^{-1}\right)$, which is only six times lower than that of the aqua ion $\left[\mathrm{Gd}\left(\mathrm{H}_{2} \mathrm{O}\right)_{8}\right]^{3+}$ ion $\left(800 \times 10^{6} \mathrm{~s}^{-1}\right)$. The reason for this very fast exchange is likely the high flexibility of the inner coordination sphere around the binding site of the three hydration water molecules, despite the rigid ligand structure. In addition, the negative value of the activation entropy points to an associatively activated mechanism for $[\mathrm{Gd}(\mathrm{L} 1)]^{-}$which means that the incoming water molecule has also a role in the rate determining step. While only the determination of activation volumes via variable pressure ${ }^{17} \mathrm{O}$ NMR measurements would allow for a precise assessment of the water exchange mechanism, activation entropies also provide a hint. ${ }^{30}$ On the other hand, $[\mathrm{Gd}(\mathrm{L} 2)]^{-}$and $[\mathrm{Gd}(\mathrm{L} 3)]^{-}$are characterized by an interchange or slightly dissociatively activated water exchange mechanism (the activation entropy is close to zero or has a small 
positive value), in contrast to the high positive $\Delta S^{t}$ value for $[\operatorname{Gd}(\mathrm{DTPA})]^{2-}$, clearly indicating a dissociative mechanism.

Table 7. Relaxivities $\left(20 \mathrm{MHz}, 25^{\circ} \mathrm{C}\right)$ and Parameters Obtained from the Simultaneous Fitting of ${ }^{17} \mathrm{O}$ NMR and NMRD Data for $[\mathrm{Gd}(\mathrm{L1})]^{-},[\mathrm{Gd}(\mathrm{L} 2)]^{-}$and $[\mathrm{Gd}(\mathrm{L3})]^{-}$and Literature Values for Related Complexes [Gd(HYD) $]^{-} 9^{b}$ and [Gd(DTPA) $]^{2-} \cdot{ }^{27}$

\begin{tabular}{|c|c|c|c|c|c|c|}
\hline & {$[\mathrm{Gd}(\mathrm{L} 1)]^{-}$} & {$[\mathrm{Gd}(\mathrm{L} 2)]^{-}$} & {$[\mathrm{Gd}(\mathrm{L} 3)]^{-}$} & {$[\mathrm{Gd}(\mathrm{HYD})]^{-} 9^{b}$} & {$[\mathrm{Gd}(\mathrm{CyPic} 3 \mathrm{~A})]^{-}$} & {$[\mathrm{Gd}(\mathrm{DTPA})]^{2-27}$} \\
\hline$k_{\mathrm{ex}}^{298}\left(10^{6} \mathrm{~s}^{-1}\right)$ & $127 \pm 15$ & $10.0 \pm 2.3$ & $8.1 \pm 0.5$ & 7.8 & 44 & 3.3 \\
\hline$\Delta H^{t}\left(\mathrm{~kJ} \mathrm{~mol}^{-1}\right)$ & $21.7 \pm 3.6$ & $36.1 \pm 1.6$ & $27.6 \pm 1.7$ & 43.5 & 29.1 & 51.6 \\
\hline$\Delta S^{t}\left(\mathrm{~J} \mathrm{~mol}^{-1} \mathrm{~K}^{-1}\right)$ & $-17 \pm 7$ & $+10 \pm 4$ & $-1 \pm 5$ & +33 & - & +53 \\
\hline$\tau_{\mathrm{RH}}{ }^{298}(\mathrm{ps})$ & $66 \pm 2$ & $92 \pm 3$ & $119 \pm 2$ & 92.6 & - & 58 \\
\hline$\tau_{\mathrm{v}}^{298}(\mathrm{ps})$ & $15 \pm 2$ & $2.6 \pm 0.5$ & $3.8 \pm 0.2$ & 2.1 & - & \\
\hline$E_{R}\left(\mathrm{~kJ} \mathrm{~mol}^{-1}\right)$ & $23.8 \pm 0.6$ & $20.1 \pm 1.3$ & $20.5 \pm 0.7$ & 21.0 & - & 17.3 \\
\hline$A / \hbar\left(10^{6} \mathrm{rad} \mathrm{s}^{-1}\right)$ & $-3.1 \pm 0.2$ & $-3.0 \pm 0.4$ & $-3.1 \pm 0.3$ & -4.0 & - & -3.8 \\
\hline$\Delta^{2}\left(10^{20} \mathrm{~s}^{-2}\right)$ & $0.44 \pm 0.07$ & $0.46 \pm 0.13$ & $0.40 \pm 0.02$ & 0.55 & - & \\
\hline$q$ & 3 & 2 & 1 & 2 & 2 & 1 \\
\hline
\end{tabular}

The calculated values of the rotational correlation time, $\tau_{R H^{298}}$, were 66,92 , and 119 ps, for $[\mathrm{Gd}(\mathrm{L} 1)]^{-},[\mathrm{Gd}(\mathrm{L} 2)]^{-}$and $[\mathrm{Gd}(\mathrm{L} 3)]^{-}$, respectively, in accordance with their increasing size. The small differences in the relaxivity of the three complexes can be related to the opposing effects of the decreasing hydration number and the increasing size, hence rotational correlation time in the order of $[\mathrm{GdL} 1]^{-},[\mathrm{Gd}(\mathrm{L} 2)]^{-}$and $[\mathrm{Gd}(\mathrm{L} 3)]^{-}$. The water exchange rate has no influence on relaxivity for such small complexes; their relaxivity is only limited by fast rotation. 


\section{CONCLUSIONS}

In this work, we have described efficient syntheses of three different ligands containing a rigid $(1 S, 2 S)$-1,2-cyclobutanediamine spacer and a different number of acetate and picolinate groups. We have shown that this versatile spacer can be easily functionalized with different coordinating groups, providing a new structural entry for ligand design to coordination chemists. We expected that the rigid nature of the $(1 S, 2 S)$ 1,2-cyclobutanediamine group could provide $\mathrm{Gd}^{3+}$ complexes with high kinetic inertness. Although detailed dissociation kinetic data could not be obtained for $[\mathrm{Gd}(\mathrm{L} 3)]^{-}$, thermodynamic and luminescence studies as well as computational calculations suggest that the octadentate ligand (L3) ${ }^{4-}$ forms a stable, monohydrated complex with $\mathrm{Gd}^{3+}$ which is very labile. The detailed thermodynamic and kinetic studies presented here clearly show that the octadentate ligand (L3) $)^{4-}$ forms a labile monohydrated complex with $\mathrm{Gd}^{3+}$. In contrast, the complex with the heptadentate $(\mathrm{L} 2)^{4-}$ ligand presents a much higher kinetic inertness together with a rather high relaxivity associated to the presence of two coordinated water molecules. While the inertness of the complex is not good enough to conceive any in vivo application as an MRI contrast agent, this complex represents a rare case in which lowering ligand denticity causes a noticeable increase in kinetic inertness. ${ }^{31}$ A structural analysis suggests that the large bite angle of the $(1 S, 2 S)$-1,2-cyclobutanediamine spacer can make ligands based on this scaffold more suitable for the coordination of bulkier metal ions. Future work will expand the family of ligands presented here and will explore their coordination properties toward other metal ions with relevant biomedical applications.

\section{EXPERIMENTAL SECTION}


acetate (3): To a solution of $2(65.6 \mathrm{mg}, 0.75 \mathrm{mmol})$, prepared according to reference 10 , potassium iodide (480 $\mathrm{mg}, 2.89 \mathrm{mmol}, 3.85 \mathrm{eq}$ ), and diisopropylethylamine (DIPEA) (1.08 $\mathrm{mL}$, $6.2 \mathrm{mmol}, 8.3 \mathrm{eq})$ in DMF ( $2 \mathrm{~mL})$ was added tert-butyl bromoacetate $(0.49 \mathrm{~mL}, 3.3 \mathrm{mmol}, 4.4$ eq) and the reaction mixture was stirred at room temperature for $18 \mathrm{~h}$ under $\mathrm{N}_{2}$ atmosphere. Then, the solution was diluted with $\mathrm{CH}_{2} \mathrm{Cl}_{2}(20 \mathrm{~mL})$ and washed with saturated $\mathrm{K}_{2} \mathrm{CO}_{3}(2 \times 5 \mathrm{~mL})$, and brine $(1 \times 5 \mathrm{~mL})$. The organic layer was dried over $\mathrm{MgSO}_{4}$, filtered and evaporated under reduced pressure. Purification by column chromatography (1:3 EtOAc/hexane) afforded $\mathbf{3}$ ( $288 \mathrm{mg}, 0.53$ mmol, $70 \%$ yield $)$ as a yellow oil. $[\alpha]_{D}^{20}:+8\left(c=1.0, \mathrm{CH}_{3} \mathrm{OH}\right) ;{ }^{1} \mathrm{H} \mathrm{NMR}\left(360 \mathrm{MHz}, \mathrm{CDCl}_{3}\right): \delta 1.44$ (s, 28H, $\left.{ }^{t} \mathrm{Bu}, \mathrm{H}_{3}, \mathrm{H}_{4}\right), 1.79$ (m, 2H, $\left.\mathrm{H}_{3}{ }^{\prime}, \mathrm{H}_{4}{ }^{\prime}\right), 3.32$ (m, 2H, $\left.\mathrm{H}_{1}, \mathrm{H}_{2}\right), 3.41$ (m, 1H, $\left.\mathrm{H}_{5}\right), 3.46$ (m, 3H, $\left.\mathrm{H}_{5}\right), 3.49\left(\mathrm{~m}, 3 \mathrm{H}, \mathrm{H}_{5}\right), 3.54\left(\mathrm{~m}, 1 \mathrm{H}, \mathrm{H}_{5}\right) ;{ }^{13} \mathrm{C} \mathrm{NMR}\left(90 \mathrm{MHz}, \mathrm{CDCl}_{3}\right): \delta 20.3\left(\mathrm{C}_{3}, \mathrm{C}_{4}\right), 28.1(t \mathrm{Bu})$, $52.9\left(\mathrm{C}_{5}\right), 62.9\left(\mathrm{C}_{1}, \mathrm{C}_{2}\right), 80.6(\mathrm{C}-t \mathrm{Bu}), 171.1(\mathrm{CO})$. IR (ATR): $v 2978,2931,1729 \mathrm{~cm}^{-1}$; HRMS (ESI) $m / z$ calcd for $\mathrm{C}_{28} \mathrm{H}_{51} \mathrm{~N}_{2} \mathrm{O}_{8}[\mathrm{M}+\mathrm{H}]^{+}:$543.3640. Found: 543.3647.

2,2',2",2'"'-[\{(1S,2S)-Cyclobutane-1,2-diyl $\}$ bis(azanediyl)]tetraacetic acid (H4cbdta, $\left.\mathbf{H}_{4}(\mathbf{L 1})\right)$ : A solution of compound $3(180 \mathrm{mg}, 0.33 \mathrm{mmol})$ in $4 \mathrm{M} \mathrm{HCl}$ in dioxane $(12 \mathrm{~mL})$ was stirred at room temperature for $18 \mathrm{~h}$. Then, the solvent was evaporated under reduced pressure, and a small amount of water $(2 \mathrm{~mL})$ was added and the mixture was evaporated to dryness. This process was repeated once with the addition of water and twice with an addition of diethyl ether $(2 \mathrm{~mL})$ to afford the desired ligand $\left(110 \mathrm{mg}, 0.25 \mathrm{mmol}, 77 \%\right.$ yield) as a yellow solid. ${ }^{1} \mathrm{H}$ NMR (600 MHz, $\left.\mathrm{D}_{2} \mathrm{O}\right): \delta 1.67\left(\mathrm{~m}, 2 \mathrm{H}, \mathrm{H}_{3}, \mathrm{H}_{4}\right), 1.97\left(\mathrm{~m}, 2 \mathrm{H}, \mathrm{H}_{3}, \mathrm{H}_{4}\right), 3.88\left(\mathrm{~m}, 8 \mathrm{H}, \mathrm{H}_{5}\right), 3.94(\mathrm{~m}, 2 \mathrm{H}$, $\left.\mathrm{H}_{1}, \mathrm{H}_{2}\right) ;{ }^{13} \mathrm{C}$ NMR (150 MHz, $\left.\mathrm{D}_{2} \mathrm{O}\right): \delta 18.1\left(\mathrm{C}_{3}, \mathrm{C}_{4}\right), 52.5\left(\mathrm{C}_{5}\right), 61.7\left(\mathrm{C}_{1}, \mathrm{C}_{2}\right), 171.2(\mathrm{CO})$. HRMS (ESI) $\mathrm{m} / z$ calcd for $\mathrm{C}_{12} \mathrm{H}_{18} \mathrm{~N}_{2} \mathrm{O}_{8} \mathrm{Na}[\mathrm{M}+\mathrm{Na}]^{+}:$341.0961. Found: 341.0962 .

Methyl 6-[\{(1S,2S)-cyclobutane-1,2-diylbis[(2-tert-butoxycarbonyl)azanediyl] $\}$ (methylene)]picolinate (6): Aldehyde $5(0.124 \mathrm{~g}, 0.75 \mathrm{mmol}, 1 \mathrm{eq})$, prepared according to reference $2 \mathrm{~h}$, was added to a solution of $4^{10}(140 \mathrm{mg}, 0.75 \mathrm{mmol})$ in $\mathrm{CH}_{3} \mathrm{OH}(5 \mathrm{~mL})$ and the reaction mixture was stirred at room temperature for $2.5 \mathrm{~h}$. Small aliquots of this reaction were removed and concentrated to dryness for NMR analysis to confirm full Schiff base formation. Then, the reaction was diluted with $\mathrm{CH}_{3} \mathrm{OH}(5 \mathrm{~mL})$, cooled to $0{ }^{\circ} \mathrm{C}$ and then $\mathrm{NaBH}_{4}(31 \mathrm{mg}, 0.81$ mmol) was added. After $2 \mathrm{~h}$ of stirring at $0{ }^{\circ} \mathrm{C}$, the reaction was quenched with satd. $\mathrm{NaHCO}_{3}$ and extracted with $\mathrm{CH}_{2} \mathrm{Cl}_{2}$. The organic layer was dried over $\mathrm{MgSO}_{4}$, filtered and evaporated under reduced pressure to afford $6(218 \mathrm{mg}, 0.65 \mathrm{mmol}, 87 \%$ yield $)$ as a yellow oil. $[\alpha]_{D}^{20}:+5(c=1.0$, $\left.\mathrm{CH}_{3} \mathrm{OH}\right) ;{ }^{1} \mathrm{H}$ NMR $\left(400 \mathrm{MHz}, \mathrm{CDCl}_{3}\right): \delta 1.42\left(\mathrm{~s}, 11 \mathrm{H},{ }^{t} \mathrm{Bu}, \mathrm{H}_{3}, \mathrm{H}_{4}\right), 1.95(\mathrm{~m}, 1 \mathrm{H}), 2.12(\mathrm{~m}, 1 \mathrm{H})$, 2.87 (br s, 2H, NH), $3.15(\mathrm{~m}, 1 \mathrm{H}), 3.79(\mathrm{~m}, 1 \mathrm{H}), 3.98$ (s, 3H, Me), $4.01\left(\mathrm{~m}, 2 \mathrm{H}, \mathrm{H}_{5}\right), 7.55(\mathrm{~m}$, 1H), $7.78(\mathrm{~m}, 1 \mathrm{H}), 7.97(\mathrm{~m}, 1 \mathrm{H}) ;{ }^{13} \mathrm{C} \mathrm{NMR}\left(90 \mathrm{MHz}, \mathrm{CDCl}_{3}\right): \delta 23.3,23.5,28.3,52.2,52.8,61.5$, 64.5, 77.2, 123.7, 125.7, 137.6, 146.9, 154.9, 160.3, 165.5; IR (ATR): v 3117, 2975, $1687 \mathrm{~cm}^{-1}$; HRMS (ESI) $m / z$ calcd for $\mathrm{C}_{17} \mathrm{H}_{25} \mathrm{~N}_{3} \mathrm{O}_{4} \mathrm{Na}[\mathrm{M}+\mathrm{Na}]^{+}: 358.1737$. Found: 358.1724 . 


\section{Methyl 6-[\{(1S,2S)-cyclobutane-1,2-diyltris[(2-tert-butoxy-2-oxoethyl)azanediyl]\}}

(methylene)] picolinate (7): Diamine 6 (218 mg, $0.65 \mathrm{mmol}$ ) was dissolved in $\mathrm{CH}_{2} \mathrm{Cl}_{2}(5 \mathrm{~mL})$. Then, a solution of $1 \mathrm{M} \mathrm{HCl}$ in EtOAc $(11.25 \mathrm{~mL}, 11.25 \mathrm{mmol}, 15 \mathrm{eq})$ was added and the reaction was stirred at r.t. for $4 \mathrm{~h}$. The solvent was evaporated under reduced pressure. Then, the crude product was dissolved in $\mathrm{CH}_{2} \mathrm{Cl}_{2}(20 \mathrm{~mL})$ and stirred over an excess of $\mathrm{K}_{2} \mathrm{CO}_{3}(0.83 \mathrm{~g}, 6 \mathrm{mmol})$. After $2 \mathrm{~h}$, the solution was filtered and evaporated. The slurry containing product and $\mathrm{K}_{2} \mathrm{CO}_{3}$ could be carried directly through to the next step (assuming 100\% deprotected amine). Then, the mixture was dissolved in DMF (2 mL) under $\mathrm{N}_{2}$ atmosphere. $\mathrm{KI}(0.312 \mathrm{~g}, 1.88 \mathrm{mmol}, 2.89 \mathrm{eq})$, DIPEA (0.71 mL, $4.10 \mathrm{mmol}, 6.3 \mathrm{eq})$ and tert-butyl bromoacetate $(0.315 \mathrm{~mL}, 2.14 \mathrm{mmol}, 3.3 \mathrm{eq})$ were added and the reaction mixture was stirred at r.t. for $18 \mathrm{~h}$. Then, the solution was diluted with $\mathrm{CH}_{2} \mathrm{Cl}_{2}(20 \mathrm{~mL})$ and washed with saturated $\mathrm{K}_{2} \mathrm{CO}_{3}(2 \times 5 \mathrm{~mL})$, and brine $(1 \times 5 \mathrm{~mL})$. The organic layer was dried over $\mathrm{MgSO}_{4}$, filtered and evaporated under reduced pressure. Purification by column chromatography (1:3 to 1:1 mixtures of EtOAc/hexane) affords 7 (263 mg, 0.455 mmol, $74 \%$ yield $)$ as a yellow oil. $[\alpha]_{D}^{20}:+17\left(c=1.0, \mathrm{CH}_{3} \mathrm{OH}\right) ;{ }^{1} \mathrm{H}$ NMR $\left(400 \mathrm{MHz}, \mathrm{CDCl}_{3}\right)$ : $\delta 1.43\left(\mathrm{~m}, 29 \mathrm{H},{ }^{t} \mathrm{Bu}, \mathrm{H}_{3}, \mathrm{H}_{4}\right), 1.82\left(\mathrm{~m}, 2 \mathrm{H}, \mathrm{H}_{3}, \mathrm{H}_{4}\right), 3.32(\mathrm{~m}, 3 \mathrm{H}), 3.48(\mathrm{~m}, 5 \mathrm{H}), 3.99$ (s, 3H, Me), $4.02\left(\mathrm{~m}, 1 \mathrm{H}, \mathrm{H}_{6}\right), 4.09$ (m, 1H, H6' $), 7.80$ (t, 1H, J = 7.6 Hz, H8), 7.91 (d, 1H, J = 7.6 Hz), 7.98 $(\mathrm{d}, 1 \mathrm{H}, J=7.5 \mathrm{~Hz}) ;{ }^{13} \mathrm{C} \mathrm{NMR}\left(100 \mathrm{MHz}, \mathrm{CDCl}_{3}\right): \delta 18.6,20.5,28.0,28.1,52.7,54.1,56.8,61.8$, 63.3, 80.6, 123.4, 126.1, 137.2, 147.0, 161.2, 165.9, 170.9; IR (ATR): $v 2978,1722 \mathrm{~cm}^{-1}$; HRMS (ESI) $m / z$ calcd for $\mathrm{C}_{30} \mathrm{H}_{47} \mathrm{~N}_{3} \mathrm{O}_{8} \mathrm{Na}[\mathrm{M}+\mathrm{Na}]^{+}: 600.3255$. Found: 600.3267 .

\section{6-[\{(1S,2S)-cyclobutane-1,2-diyltris[(carboxymethyl)-azanediyl]\}(methylene)] picolinic} acid $\left(\mathbf{H}_{4} \mathbf{c b d d a p a}, \mathbf{H}_{4}(\mathbf{L 2})\right)$ : A solution of compound $7(180 \mathrm{mg}, 0.31 \mathrm{mmol})$ was dissolved in $\mathrm{THF} / \mathrm{H}_{2} \mathrm{O}(1: 1,5 \mathrm{~mL})$. Then $\mathrm{LiOH}(0.052 \mathrm{~g}, 1.25 \mathrm{mmol}, 4 \mathrm{eq})$ was added and the reaction mixture was subsequently stirred at room temperature for $4 \mathrm{~h}$ and concentrated to dryness under reduced pressure. The resultant residue was dissolved in $4 \mathrm{M} \mathrm{HCl}$ in dioxane $(8 \mathrm{~mL})$ and stirred at room temperature for $18 \mathrm{~h}$. The solvent was evaporated under reduced pressure. A small amount of water $(2 \mathrm{~mL})$ was added and the mixture was evaporated to dryness. This process was repeated once with the addition of water and twice with an addition of diethyl ether $(2 \mathrm{~mL})$ to afford the desired ligand (110 mg, $0.25 \mathrm{mmol}, 77 \%$ yield) as a yellow solid. ${ }^{1} \mathrm{H}$ NMR (600 MHz, $\left.\mathrm{D}_{2} \mathrm{O}\right)$ : $\delta 1.75\left(\mathrm{~m}, 2 \mathrm{H}, \mathrm{H}_{3}, \mathrm{H}_{4}\right), 2.06\left(\mathrm{~m}, 2 \mathrm{H}, \mathrm{H}_{3}{ }^{\prime}, \mathrm{H}_{4}{ }^{\prime}\right), 3.76(\mathrm{~m}, 1 \mathrm{H}), 3.75(\mathrm{~m}, 1 \mathrm{H}), 3.83(\mathrm{~m}, 1 \mathrm{H}), 4.00$ $(\mathrm{m}, 4 \mathrm{H}), 4.16(\mathrm{~m}, 1 \mathrm{H}), 4.32\left(\mathrm{~m}, 2 \mathrm{H}, \mathrm{H}_{6}\right), 8.01(\mathrm{~d}, 1 \mathrm{H}, J=7.7 \mathrm{~Hz}), 8.28(\mathrm{~d}, 1 \mathrm{H}, J=6.2 \mathrm{~Hz}), 8.46$ $\left(\mathrm{t}, 1 \mathrm{H}, J=7.6 \mathrm{~Hz}, \mathrm{H}_{8}\right) .{ }^{13} \mathrm{C} \mathrm{NMR}\left(150 \mathrm{MHz}, \mathrm{D}_{2} \mathrm{O}\right): \delta 17.3,18.2,52.0,53.1,53.4,60.6,62.3$, 126.2, 129.0, 146.6, 154.0, 163.0, 168.7, 174.25. HRMS (ESI) $\mathrm{m} / z$ calcd for $\mathrm{C}_{17} \mathrm{H}_{21} \mathrm{~N}_{3} \mathrm{O}_{8} \mathrm{Na}$ $[\mathrm{M}+\mathrm{Na}]^{+}:$418.1226. Found: 418.1221.

Dibenzyl [(1S,2S)-cyclobutane-1,2-diyl]dicarbamate (8): To an ice cooled solution of $\mathbf{1}^{10}$ $(0.160 \mathrm{~g}, 0.73 \mathrm{mmol})$ in water $(30 \mathrm{~mL})$ and acetone $(4 \mathrm{~mL}), \mathrm{NaHCO}_{3}(0.120 \mathrm{~g}, 1.45 \mathrm{mmol}, 2 \mathrm{eq})$ and $\mathrm{Na}_{2} \mathrm{CO}_{3}(0.230 \mathrm{~g}, 2.20 \mathrm{mmol}, 3 \mathrm{eq})$ were added. The mixture was stirred until the complete 
dissolution of the carbonates. Then, benzyl chloroformate $(0.2 \mathrm{~mL}, 1.20 \mathrm{mmol}, 1.6 \mathrm{eq})$ was added and the mixture was stirred at $0{ }^{\circ} \mathrm{C}$ (reaction was monitored by TLC). After $18 \mathrm{~h}$, the reaction was extracted with EtOAc $(4 \times 50 \mathrm{~mL})$ and the organic layer was dried over magnesium sulfate. The solvent was removed under vacuum, and the excess of benzyl chloroformate was lyophilized. The residue was purified by column chromatography (2:1 hexane-EtOAc) to afford diprotected amine $8(0.155 \mathrm{~g}, 0.44 \mathrm{mmol}, 60 \%$ yield $)$ as a white solid. M.p: $70-73^{\circ} \mathrm{C}($ EtOAc $) ;[\alpha]_{\mathrm{D}}=-10.0(c=1.00$ in $\mathrm{MeOH}) ;{ }^{1} \mathrm{H} \mathrm{NMR}\left(400 \mathrm{MHz}, \mathrm{CDCl}_{3}\right): \delta 1.54\left(\mathrm{~m}, 2 \mathrm{H}, \mathrm{H}_{3}, \mathrm{H}_{4}\right), 2.17\left(\mathrm{~m}, 2 \mathrm{H}, \mathrm{H}_{3}, \mathrm{H}_{4}\right), 3.93(\mathrm{~m}$, $2 \mathrm{H}, \mathrm{H}_{1}, \mathrm{H}_{2}$ ), 5.11 (m, $\mathrm{CH}_{2}-\mathrm{Ph}$ ), 5.19 (br. 2H, NH), 7.37 (s, 10H, Ar); ${ }^{13} \mathrm{C} \mathrm{NMR}(100 \mathrm{MHz}$, $\left.\mathrm{CDCl}_{3}\right): \delta 23.5\left(\mathrm{C}_{3}, \mathrm{C}_{4}\right), 53.4\left(\mathrm{C}_{1}, \mathrm{C}_{2}\right), 66.7\left(\mathrm{CH}_{2}-\mathrm{Ph}\right), 128.1(\mathrm{Ar}), 128.5(\mathrm{Ar}), 136.3(\mathrm{Ar}), 155.6$ (CO); IR (ATR): v $3306\left(\mathrm{NH}_{\mathrm{st}}\right), 2975\left(\mathrm{CH}_{\mathrm{st}}\right), 1682(\mathrm{C}=\mathrm{O}) \mathrm{cm}^{-1}$; HRMS (ESI): $\mathrm{m} / z$ calcd for $\mathrm{C}_{24} \mathrm{H}_{24} \mathrm{~N}_{2} \mathrm{O}_{6} \mathrm{Na}[\mathrm{M}+\mathrm{Na}]^{+}$: 377.1472. Found: 377.1466.

\section{Di-tert-butyl 2,2'-[(1S,2S)-cyclobutane-1,2-diyl)bis(benzyloxycarbonylazanediyl)]} diacetate (9): To a solution of anhydrous THF ( $8 \mathrm{~mL}$ ) containing previously washed $60 \% \mathrm{NaH}$ in mineral oil (280 mg, $7 \mathrm{mmol}, 10 \mathrm{eq}$ ), TBAI (1.55 g, $4.20 \mathrm{mmol}, 6 \mathrm{eq})$ was added under nitrogen atmosphere. At the same time, a solution of anhydrous THF $(10 \mathrm{~mL})$ containing diprotected amine 8 (250 mg, $0.70 \mathrm{mmol})$ under nitrogen atmosphere was prepared. After that, the second solution was added using a cannula connected to the first one. Finally, tert-butyl bromoacetate $(0.620 \mathrm{~mL}$, $4.20 \mathrm{mmol}, 6 \mathrm{eq}$ ) was added ant the mixture was stirred at room temperature for $24 \mathrm{~h}$ (reaction was monitored by TLC). Then, the reaction was quenched by adding $10 \mathrm{~mL}$ of water and THF was removed under vacuum. Next, more water was added $(10 \mathrm{~mL})$ and the crude was extracted with dichloromethane $(3 \times 30 \mathrm{~mL})$ The organic layer was dried over magnesium sulfate and the solvent was removed under vacuum. The residue was purified by column chromatography (3:1 hexane-EtOAc) to afford dialkylated diamine 9 (250 mg, 62\% yield) as a brown oil along with the corresponding monoalkylated product ( $64 \mathrm{mg}, 21 \%$ yield) that was submitted to further alkylation under similar conditions. $[\alpha]_{\mathrm{D}}=+2.00(c=1.02$ in $\mathrm{MeOH}) ;{ }^{1} \mathrm{H}$ NMR $(400 \mathrm{MHz}$, $\left.\mathrm{CDCl}_{3}\right) \delta 1.27-1.52\left(\mathrm{~m}, 18 \mathrm{H},{ }^{\mathrm{t}} \mathrm{Bu}\right), 1.52-1.73\left(\mathrm{~m}, 2 \mathrm{H}, \mathrm{H}_{3}, \mathrm{H}_{4}\right), 1.94-2.13\left(\mathrm{~m}, 2 \mathrm{H}, \mathrm{H}_{3^{\prime}}, \mathrm{H}_{4}{ }^{\prime}\right), 3.68-$ 4.18 (m, 4H, $\mathrm{H}_{5}$ ), 4.37-4.60 (m, 2H, $\mathrm{H}_{1}, \mathrm{H}_{2}$ ), 5.12 (m, 4H, $\left.\mathrm{CH}_{2}-\mathrm{Ph}\right), 7.33$ (m, 10H, Ar); IR (ATR): v 2978 (CHst), $1743(\mathrm{C}=\mathrm{O}), 1709(\mathrm{C}=\mathrm{O}) \mathrm{cm}^{-1}$; HRMS (ESI): $\mathrm{m} / z$ calcd for $\mathrm{C}_{24} \mathrm{H}_{24} \mathrm{~N}_{2} \mathrm{O}_{6} \mathrm{Na}$ $[\mathrm{M}+\mathrm{Na}]^{+}:$605.2833. Found: 605.2830.

Dimethyl 6,6'-[\{(1S,2S)-cyclobutane-1,2-diylbis[(2-tert-butoxy-2-oxoethyl)azanediyl]\}bis(methylene)] dipicolinate (11): Dialkylated diamine 9 (230 mg, $0.73 \mathrm{mmol}$ ), KI (365mg, $2.20 \mathrm{mmol}, 1.5 \mathrm{eq}$ ) and methyl 6-(chloromethyl)picolinate, 10 ${ }^{[32]}$ (300 mg, $1.60 \mathrm{mmol}$, $1.1 \mathrm{eq})$ were dissolved in anhydrous DMF $(10 \mathrm{~mL})$ under nitrogen atmosphere. After that, DIPEA $(0.820 \mathrm{~mL}, 4.70 \mathrm{mmol}, 3.2 \mathrm{eq})$ was added and the reaction was stirred at room temperature for 30 hours. Then, EtOAc $(30 \mathrm{~mL})$ was added and washes with saturated $\mathrm{NaHCO}_{3}(3 \times 20 \mathrm{~mL})$, brine $(3 \times 20 \mathrm{~mL})$ and water $(1 \times 20 \mathrm{~mL})$ were carried out. The final organic layer was dried over magnesium sulfate and the solvent was removed under vacuum. The residue was purified by 
column chromatography over silica gel with a gradient of solvents (3:1 to 1:1 mixtures of HexaneEtOAc) to afford $11(270 \mathrm{mg}, 0.42 \mathrm{mmol}, 57 \%$ yield $)$ as a brown oil. $[\alpha]_{\mathrm{D}}=+18.0(c=1.01 \mathrm{in}$ $\mathrm{MeOH}) ;{ }^{1} \mathrm{H}$ NMR (400 MHz, $\left.\mathrm{CDCl}_{3}\right): \delta 1.39$ (s, $\left.18 \mathrm{H},{ }^{\mathrm{t}} \mathrm{Bu}\right), 1.41-1.50\left(\mathrm{~m}, 2 \mathrm{H}, \mathrm{H}_{4 R}, \mathrm{H}_{3 S}\right), 1.73-$ 1.89 (m, 2H, $\left.\mathrm{H}_{45}, \mathrm{H}_{3 R}\right), 3.25$ (s, 4H, $\mathrm{H}_{5}$ ), 3.41 (m, 2H, H, $\mathrm{H}_{2}$ ), 3.98 (s, 6H, Me), 4.05 (s, 4H, $\mathrm{H}_{6}$ ), 7.73 (m, 2H, Ar), 7.86 (m, 2H, Ar), 7.96 (m, 2H, Ar); $\left.{ }^{13} \mathrm{C} \mathrm{NMR} \mathrm{(100} \mathrm{MHz,} \mathrm{CDCl}_{3}\right): \delta 19.3\left(\mathrm{C}_{3}\right.$, $\left.\mathrm{C}_{4}\right), 28.1\left(\mathrm{CH}_{3}{ }^{-} \mathrm{Bu}\right), 52.8\left(\mathrm{CH}_{3}\right), 53.8\left(\mathrm{C}_{5}\right), 57.0\left(\mathrm{C}_{6}\right), 62.6\left(\mathrm{C}_{1}, \mathrm{C}_{2}\right), 80.8\left(\mathrm{C}-{ }^{-} \mathrm{Bu}\right), 123.4(\mathrm{Ar})$, 126.2 (Ar), 137.2 (Ar), 147.1 (Ar), 161.3 (Ar), 165.9 (CO), 170.8 (CO); IR (ATR): v 2977 (CHst), 2951 (CHst), $1721(\mathrm{C}=\mathrm{O}), 1589(\mathrm{C}=\mathrm{O}) \mathrm{cm}^{-1}$; HRMS (ESI): $\mathrm{m} / z$ calcd for $\mathrm{C}_{24} \mathrm{H}_{24} \mathrm{~N}_{2} \mathrm{O}_{6} \mathrm{Na}$ $[\mathrm{M}+\mathrm{Na}]^{+}:$613.3232. Found: 613.3231.

\section{6,6'-[\{(1S,2S)-cyclobutane-1,2-diylbis[(carboxymethyl)azanediyl]\}bis(methylene)]}

dipicolinic acid ( $\left.\mathbf{H}_{4} \mathbf{c b d d a d p a}, \mathbf{H}_{4}(\mathbf{L} 3)\right)$ : Compound $\mathbf{1 1}(150 \mathrm{mg}, 0.245 \mathrm{mmol})$ was dissolved in $\mathrm{THF} / \mathrm{H}_{2} \mathrm{O}(1: 1,5 \mathrm{~mL}), \mathrm{LiOH}(31.0 \mathrm{mg}, 0.740 \mathrm{mmol}, 3 \mathrm{eq})$ was added and the reaction mixture was stirred at room temperature for $4 \mathrm{~h}$. Then, the mixture was concentrated to dryness under reduced pressure and the resultant residue was dissolved in $4 \mathrm{M} \mathrm{HCl}$ in dioxane $(3 \mathrm{~mL})$ and stirred at room temperature for $18 \mathrm{~h}$. Then, the solvent was evaporated under reduced pressure. A small amount of water $(3 \mathrm{~mL})$ was added and the mixture was evaporated to dryness. This process was repeated twice with water and twice with the addition of diethyl ether $(3 \mathrm{~mL})$ to afford the desired ligand (100 mg, $0.184 \mathrm{mmol}, 75 \%$ yield) as a brown solid. $[\alpha]_{\mathrm{D}}=+36.00\left(c=1.00\right.$ in $\left.\mathrm{H}_{2} \mathrm{O}\right) ;{ }^{1} \mathrm{H}$ NMR (400 MHz, $\left.\mathrm{D}_{2} \mathrm{O}\right): \delta 1.72-1.82\left(\mathrm{~m}, 2 \mathrm{H}, \mathrm{H}_{4 R}, \mathrm{H}_{3 S}\right), 2.04-2.17\left(\mathrm{~m}, 2 \mathrm{H}, \mathrm{H}_{4 S}, \mathrm{H} 3_{R}\right), 3.71-3.91$ (m, 4H, $\left.\mathrm{H}_{5}\right), 4.16\left(\mathrm{~m}, 2 \mathrm{H}, \mathrm{H}_{1}, \mathrm{H}_{2}\right), 4.46\left(\mathrm{~s}, 4 \mathrm{H}, \mathrm{H}_{6}\right), 7.76$ (m, 2H, Ar), 8.04 (m, 2H, Ar), 8.17 (m, 2H, Ar); ${ }^{13} \mathrm{C}$ NMR (100 MHz, $\left.\mathrm{D}_{2} \mathrm{O}\right): \delta 17.7\left(\mathrm{C}_{3}, \mathrm{C}_{4}\right), 52.1\left(\mathrm{C}_{5}\right), 55.1\left(\mathrm{C}_{6}\right), 51.5\left(\mathrm{C}_{1}, \mathrm{C}_{2}\right), 125.9$ (Ar), 128.7 (Ar), 143.8 (Ar), 144.2 (Ar), 152.0 (Ar), 164.1 (CO), 171.0 (CO); IR (ATR): v 3377 $\left(\mathrm{OH}_{\mathrm{st}}\right), 2945\left(\mathrm{CH}_{\mathrm{st}}\right), 1720(\mathrm{C}=\mathrm{O}), 1616(\mathrm{C}=\mathrm{O}) \mathrm{cm}^{-1}$; HRMS (ESI): $\mathrm{m} / z$ calcd for $\mathrm{C}_{24} \mathrm{H}_{24} \mathrm{~N}_{2} \mathrm{O}_{6} \mathrm{Na}$ $[\mathrm{M}+\mathrm{Na}]^{+}:$495.1486. Found: 495.1478 .

Sample preparation of the metal complexes. The ligand concentrations were determined based on $\mathrm{pH}$-potentiometric titration curves. $\mathrm{Gd}^{3+}, \mathrm{Zn}^{2+}$ and $\mathrm{Eu}^{3+}$ (for luminescence lifetimes) concentrations were determined by titrating the metal solutions with standardized $\mathrm{Na}_{2} \mathrm{H}_{2}$ EDTA in urotropine buffer $(\mathrm{pH} 5.6-5.8)$ in the presence of xylenol orange as an indicator. The GdL complexes have been prepared by mixing the ligand and the metal and adjusting the $\mathrm{pH}$ to 7 .

Protonation constants of ligands, stability constants of complexes and protonation constants of complexes are described and defined in Equation 3-5.

$$
\begin{array}{ll}
K_{i}=\frac{\left[H_{i} L\right]}{\left[H_{i-1} L\right]\left[H^{+}\right]} & \text {Equation 3 } \\
K_{M L}=\frac{[M L]}{[M][L]} & \text { Equation 4 }
\end{array}
$$




$$
K_{M H_{i} L}=\frac{\left[M\left(H_{i} L\right)\right]}{\left[M\left(H_{i-1} L\right)\right]\left[H^{+}\right]}
$$

Equation 5

Where $[\mathrm{M}],[\mathrm{L}]$, and $[\mathrm{ML}]$ are the equilibrium concentrations of free metal ion, deprotonated ligand, and deprotonated complex, respectively. Experimental data were refined using the computer software Hyperquad 2008. ${ }^{33}$ Species distribution plots were calculated taking the experimental constants using the computer software HySS. ${ }^{34}$ The ionic product of water used at $25^{\circ} \mathrm{C}$ was $\mathrm{pK}_{\mathrm{w}}=13.77$, while the ionic strength was kept at $0.1 \mathrm{M}$. Fixed values were used for $\mathrm{p} K_{w}$ and total concentrations of metal, ligand, and acid.

Kinetic measurements. The rates of the metal exchange reactions of $[\mathrm{Gd}(\mathrm{L} 2)]^{-}$were studied by following the formation of $[\mathrm{Cu}(\mathrm{L} 2)]^{-}$using conventional $\mathrm{UV}$-vis spectrophotometry. The exchange reactions were followed at $245 \mathrm{~nm}$ in the $\mathrm{pH}$ range of 3.35-4.90. The concentration of the complex was $0.11 \mathrm{mM}$, while $\mathrm{Cu}^{2+}$ ion was added at high excess (10-40 equivalents) to ensure pseudo-first order conditions. The temperature of the samples was kept at $25{ }^{\circ} \mathrm{C}$ and the ionic strength of the solutions was kept constant by using $0.15 \mathrm{M} \mathrm{NaCl}$. For keeping the $\mathrm{pH}$ constant, $50 \mathrm{mM}$ methylpiperazine buffer was used. The pseudo-first-order rate constants $\left(k_{o b s}\right)$ were calculated by fitting the absorbance vs time data to the monoexponential function (Equation 6).

$$
A_{t}=\left(A_{0}-A_{e}\right) e^{-k_{o b s} t}+A_{e} \quad \text { Equation } 6
$$

Where $A_{0}, A_{t}$, and $A_{e}$ are the absorbance at time $=0 \mathrm{~s}$, at time $t$, and at equilibrium, respectively. The fittings were performed with Origin 9.1 software by using standard least-squares procedure.

Relaxometric measurements. ${ }^{1} \mathrm{H}$ NMRD profiles of aqueous $1.88 \mathrm{mM}[\mathrm{Gd}(\mathrm{L} 1)]^{-}, 1.91 \mathrm{mM}$ $[\mathrm{Gd}(\mathrm{L} 2)]^{-}$, and $2.13 \mathrm{mM}[\mathrm{Gd}(\mathrm{L} 3)]^{-}$solutions $(\mathrm{pH}=7)$ were measured at 25,37 and $50{ }^{\circ} \mathrm{C}$ on a Stelar SMARTracer Fast Field Cycling NMR relaxometer $\left(0.00024-0.24 \mathrm{~T}, 0.01-10 \mathrm{MHz}{ }^{1} \mathrm{H}\right.$ Larmor frequency) and a Bruker WP80 NMR electromagnet adapted to variable-field measurements (0.47-1.88 T, 20-80 MHz), and controlled by the SMARTracer PC-NMR console. The temperature was controlled by a VTC91 temperature control unit and maintained by a gas flow. The temperature was determined according to previous calibration with a Pt resistance temperature probe.

To avoid any free $\mathrm{Gd}^{3+}$, some ligand excess was used (6\% L1; 5\% L2 and 5\% L3).

${ }^{17} \mathrm{O}$ NMR studies. Variable-temperature ${ }^{17} \mathrm{O}$ NMR measurements of aqueous solutions of GdL complexes were performed on a Bruker Advanced $400 \mathrm{MHz}$ spectrometer using a $10 \mathrm{~mm}$ BBFO probe $(9.4 \mathrm{~T}, 54.2 \mathrm{MHz})$ in the temperature range $1-75^{\circ} \mathrm{C}$. The temperature was calculated according to published calibration routines with ethylene glycol and $\mathrm{MeOH}$. Acidified water $\left(\mathrm{HClO}_{4}, \mathrm{pH}\right.$ 3.3) was used as diamagnetic reference. Transverse ${ }^{17} \mathrm{O}$ relaxation times were 
obtained by the Carl-Purcell-Meiboom-Gill spin-echo technique. To eliminate susceptibility corrections to the chemical shifts, the sample was placed in a glass sphere fixed in a $10 \mathrm{~mm} \mathrm{NMR}$ tube. To improve sensitivity, $\mathrm{H}_{2}{ }^{17} \mathrm{O}\left(10 \% \mathrm{H}_{2}{ }^{17} \mathrm{O}\right.$, CortecNet $)$ was added to achieve $\sim 1 \%{ }^{17} \mathrm{O}$ content in the sample. The $\mathrm{pH}$ of the samples was 6.5 and the GdL complex concentrations were the following: $15.3 \mathrm{mmol} / \mathrm{kg}\left([\mathrm{Gd}(\mathrm{L} 1)]^{-}\right), 13.7 \mathrm{mmol} / \mathrm{kg}\left([\mathrm{Gd}(\mathrm{L} 1)]^{-}\right)$, and $6.46 \mathrm{mmol} / \mathrm{kg}$ $\left([\mathrm{Gd}(\mathrm{L} 1)]^{-}\right)$. To avoid any free $\mathrm{Gd}^{3+}$, some ligand excess was used $(6 \% \mathrm{~L} 1 ; 5 \% \mathrm{~L} 2$ and $5 \% \mathrm{~L} 3)$.

DFT calculations. All calculations presented in this work were performed employing DFT within the hybrid meta generalized gradient approximation (hybrid meta-GGA), with the TPSSh exchange-correlation functional. ${ }^{35}$ Geometry optimizations were conducted with the Gaussian $09^{36}$ program package using the large-core approximation with the quasirelativistic effective core potential proposed by Dolg et al. ${ }^{37}$ and the associated [ $\left.5 \mathrm{~s} 4 \mathrm{p} 3 \mathrm{~d}\right]-\mathrm{GTO}$ valence basis set for Gd. The Standard 6-311G(d,p) basis set was used for all other atoms. Bulk water solvent effects were included by using the integral equation formalism variant of the polarizable continuum model (IEFPCM), ${ }^{38}$ using the universal force field (UFF) ${ }^{39}$ radii scaled by a factor of 1.1 to construct the solute cavity. Analytical second derivatives were calculated to confirm that the optimized geometries correspond to local energy minima on the potential energy surface.

Hyperfine coupling constants $A / \hbar$ were computed using the all-electron calculations with the second order Douglas-Kroll-Hess (DKH2) method $^{40}$ as implemented in ORCA (release 4.0.1.2). ${ }^{41}$ The basis sets used for these calculations included the SARC2-DKH-QZVP basis set for $\mathrm{Gd}^{42}$ and the DKH-def2-TZVP basis set for all other atoms. ${ }^{43}$ The RIJCOSX approximation ${ }^{44}$ was employed to accelerate the calculations using the SARC2-DKH-QZVP/JK auxiliary basis sets for Gd and auxiliary basis sets for all other atoms generated automatically by ORCA using AutoAux procedure. ${ }^{45}$ Solvent effects were introduced with the universal solvation model based on solute electron density and on a continuum model (SMD). ${ }^{46}$

\section{ASSOCIATED CONTENT}

\section{Supporting information}

${ }^{1} \mathrm{H}$ and ${ }^{13} \mathrm{C}$ NMR spectra of the new products, HRMS spectra of the gadolinium complexes, potentiometry studies, details on kinetic inertness studies, anion binding studies, luminescence studies, equations used for the analysis of the ${ }^{17} \mathrm{O}$ and NMRD data, references, optimized Cartesian coordinates of the complexes obtained with DFT calculations.

\section{AUTHOR INFORMATION}

\section{Corresponding Authors}

*E-mail: carlos.platas.iglesias@udc.es (C.P.-I.)

*E-mail: eva.jakabtoth@cnrs.fr (É.T.) 
*E-mail : rosa.ortuno@uab.es (R.M.O.)

\section{ORCID}

Carlos Platas-Iglesias : 0000-0002-6989-9654

Éva Tóth: 0000-0002-3200-6752

Rosa M. Ortuño: 0000-0001-7635-7354

\section{Notes}

The authors declare no competing financial interest

\section{ACKNOWLEDGMENTS}

O.P.-T. and J.A.O. thank Universitat Autònoma de Barcelona for predoctoral fellowships and O.P.-T. also for a travel grant. Financial support from Spanish Ministerio de Economía y Competitividad (grant CTQ2016-77978-R, AEI/FEDER, UE) is gratefully acknowledged. Authors thank Ana Martínez-Hernández for her assistance in the preparation of some gadolinium complexes. C. P.-I. and D. E.-G. thank Centro de Supercomputación de Galicia (CESGA) for providing the supercomputing facilities.

\section{REFERENCES}

(1) (a) The Chemistry of Contrast Agents in Medical Magnetic Resonance Imaging, second Ed.; Merbach, A.; Helm, L.; Tóth, É., Eds.; Wiley, Weinheim, 2013. (b) Theranostics and Image Guided Drug Delivery; Thanou, M., Ed; RSC, Cambridge, 2018.

(2) (a) Sarka, L.; Burai, L.; Brücher, E. The Rates of the Exchange Reactions between $[\mathrm{Gd}(\mathrm{DTPA})]^{2-}$ and the Endogenous Ions $\mathrm{Cu}^{2+}$ and $\mathrm{Zn}^{2+}$ : A Kinetic Model for the Prediction of the Magnetic Resonance Imaging. Chem. Eur. J. 2000, 6, 719-724. (b) Pasha, A.; Tircsó, G.; Benyó, E. T.; Brücher, E.; Sherry, A. D. Synthesis and Characterization of DOTA(amide)4 Derivatives: Equilibrium and Kinetic Behavior of Their Lanthanide(III) Complexes. Eur. J. Inorg. Chem. 2007, 27, 4340-4349. (c) Pálinkás, Z.; Roca-Sabio, A.; Mato-lglesias, M.; Esteban-Gómez, D.; Platas-Iglesias, C.; De Blas, A.; Rodríguez-Blas, T.; Tóth, É. Stability, Water Exchange, and Anion Binding Studies on Lanthanide(III) Complexes with a Macrocyclic Ligand Based on 1,7-Diaza-12-Crown-4: Extremely Fast Water Exchange on the $\mathrm{Gd}^{3+}$ Complex. Inorg. Chem. 2009, 48, 8878-8889. (d) McMurry, T. J.; Pippin, C. G.; Wu, C.; Deal, K. A.; Brechbiel, M.W.; Mirzadeh, S.; Gansow, O. A. Physical Parameters and Biological Stability of Yitrium(III) Diethylenetriaminepentaacetic Acid Derivative Conjugates. J. Med. Chem. 1998, 41, 3546-3549. (e) Farkas, E.; Fodor, T.; 
Kálmán, F. K.; Tircsó, G. Equilibrium and Dissociation Kinetics of the [Al(NOTA)] Complex $($ NOTA $=1,4,7-$ Triazacyclononane-1,4,7-Triacetate). In Reaction Kinetics, Mechanisms and Catalysis; 2015. (f) Tircsó, G.; Kálmán, F. K.; Pál, R.; Varga, T. R.; Király, R.; Lázár, I.; Québatte, L.; Merbach, A. E.; Tóth, É.; Brücher, E. Lanthanide Complexes Formed with the Tri- and Tetraacetate Derivatives of Bis(aminomethyl)phosphinic Acid: Equilibrium, Kinetic and NMR Spectroscopic Studies. Eur. J. Inorg. Chem. 2012, 20622073. (g) Rodríguez-Rodríguez, A.; Esteban-Gómez, D.; Tripier, R.; Tircsö, G.; Garda, Z.; Tóth, I.; De Blas, A.; Rodríguez-Blas, T.; Platas-Iglesias, C. Lanthanide(III) Complexes with a Reinforced Cyclam Ligand Show Unprecedented Kinetic Inertness. J. Am. Chem. Soc. 2014, 136, 17954-17957. h) Kálmán, F. K.; Végh, A.; Regueiro-Figueroa, M.; Tóth, É.; Platas-Iglesias, C.; Tircsó, G. H4octapa: Highly Stable Complexation of Lanthanide(III) Ions and Copper(II). Inorg. Chem. 2015, 54, 2345-2356. (i) Platas-Iglesias, C.; Mato-Iglesias, M.; Djanashvili, K.; Muller, R. N.; Vander Elst, L.; Peters, J. A.; De Blas, A.; RodríguezBlas, T. Lanthanide Chelates Containing Pyridine Units with Potential Application as Contrast Agents in Magnetic Resonance Imaging. Chem. Eur. J. 2004, 10, 3579-3590. (j) Phukan, B.; Malikidogo, K. P.; Bonnet, C.; Tóth, É.; Mondal, S.; Mukherjee, C. A Bishydrated, Eight-Coordinate Gd(III) Complex with Very Fast Water Exchange: Synthesis, Characterization, and Phantom MR Imaging. ChemistrySelect, 2018, 3, 7668-7673.

(3) Polasek, M.; Caravan, P. Is Macrocycle a Synonym for Kinetic Inertness in Gd(III) Complexes? Effect of Coordinating and Noncoordinating Substituents on Inertness and Relaxivity of Gd(III) Chelates with DO3A-like Ligands. Inorg. Chem. 2013, 52, 4084-4096.

(4) Tóth, É.; Brucher, E.; Lazar, I.; Toth, I. Kinetics of Formation and Dissociation of Lanthanide(III)-DOTA Complexes. Inorg. Chem. 1994, 33, 4070-4076.

(5) (a) Baranyai, Z.; Brucher, E.; Uggeri, F.; Maiocchi, A.; Toth, I.; Andrasi, M.; Gaspar, A.; Zekany, L.; Aime, S. The Role of Equilibrium and Kinetic Properties in the Dissociation of Gd[DTPA-Bis(methylamide)] (Omniscan) at near to Physiological Conditions. Chem. Eur. J. 2015, 21, 4789-4799. (b) Baranyai, Z.; Palinkas, Z.; Uggeri, F.; Maiocchi, A.; Aime, S.; Brucher, E. Dissociation Kinetics of Open-Chain and Macrocyclic Gadolinium(III)Aminopolycarboxylate Complexes Related to Magnetic Resonance Imaging: Catalytic Effect of Endogenous Ligands. Chem. Eur. J. 2012, 18, 16426-16435.

(6) Tircsó, G.; Regueiro-Figueroa, M.; Nagy, V.; Garda, Z.; Garai, T.; Kálmán, F. K.; EstebanGómez, D.; Tóth, É.; Platas-Iglesias, C. Approaching the Kinetic Inertness of Macrocyclic Gadolinium(III)-Based MRI Contrast Agents with Highly Rigid Open-Chain Derivatives. Chem. Eur. J. 2016, 22, 896-901.

(7) (a) Bloembergen, N.; Morgan, L. O. Proton Relaxation Times in Paramagnetic Solutions. Effects of Electron Spin Relaxation. J. Chem. Phys. 1961, 34, 842. (b) Micskei, K.; Helm, L.; Brucher, E.; Merbach, A. E. Oxygen-17 NMR Study of Water Exchange on Gadolinium 
Polyaminopolyacetates $\left[\mathrm{Gd}(\mathrm{DTPA})\left(\mathrm{H}_{2} \mathrm{O}\right)\right]^{2-}$ and $\left[\mathrm{Gd}(\mathrm{DOTA})\left(\mathrm{H}_{2} \mathrm{O}\right)\right]^{-}$Related to NMR Imaging. Inorg. Chem. 1993, 32, 3844-3850. (c) Fries, P. H.; Belorizky, E. Electronic Relaxation of Paramagnetic Metal Ions and NMR Relaxivity in Solution: Critical Analysis of Various Approaches and Application to a Gd(III)-Based Contrast Agent. J. Chem. Phys. 2005, 123, 124510-124515.

(8) Boros, E.; Caravan, P. Probing the Structure-Relaxivity Relationship of Bis-Hydrated Gd(DOTAla) Derivatives. Inorg. Chem. 2015, 54, 2403-2410.

(9) (a) Gale, E. M.; Kenton, N.; Caravan, P. [Gd(CyPic3A)( $\left.\left.\mathrm{H}_{2} \mathrm{O}\right)_{2}\right]^{-}$: a Stable Bis(aquated) and High-Relaxivity Gd(III) Complex. Chem. Commun. 2013, 49, 8060-8062. (b) Bonnet, C. S.; Laine, S.; Buron, F.; Tircsó, G.; Pallier, A.; Helm, L.; Suzenet, F.; Tóth, É. A Pyridine-Based Ligand with Two Hydrazine Functions for Lanthanide Chelation: Remarkable Kinetic Inertness for a Linear, Bishydrated Complex. Inorg. Chem. 2015, 54, 5991-6003.

(10) Sans, M.; Illa, O.; Ortuño, R. M. Stereoselective synthesis of all stereoisomers of orthogonally protected cyclobutane-1,2-diamine and some chemoselective transformations. Org. Lett. 2012, 14 , 2431-2433.

(11) Jackson, G. E.; Wynchank, S.; Woudenberg, M. Gadolinium(III) Complex Equilibria: the Implications for Gd(III) MRI Contrast Agents. Magn. Reson. Med. 1990, 16, 57-66.

(12) Kálmán, F. K.; Tircsó, G. Kinetic Inertness of the $\mathrm{Mn}^{2+}$ Complexes Formed with AAZTA and Some Open-Chain EDTA Derivatives. Inorg. Chem. 2012, 51, 10065-10067.

(13) Pellegatti, L.; Zhang, J.; Drahos, B.; Villette, S.; Suzenet, F.; Guillaumet, G.; Petoud, S.; Tóth, É. Pyridine-Based Lanthanide Complexes: Towards Bimodal Agents Operating as Near Infrared Luminescent and MRI Reporters. Chem. Commun. 2008, 60, 6591-6593.

(14) Horrocks, Jr., W. D.; Sudnick, D. R. Lanthanide Ion Probes of Structure in Biology. LaserInduced Luminescence Decay Constants Provide a Direct Measure of the Number of MetalCoordinated Water Molecules. J. Am. Chem. Soc. 1979, 101, 334-340.

(15) Horrocks, Jr., W. D.; Sudnick, D. R. Lanthanide Ion Luminescence Probes of the Structure of Biological Macromolecules. Acc. Chem. Res. 1981, 14, 384-392.

(16) Beeby, A.; Clarkson, I. M.; Dickins, R. S.; Faulkner, S.; Parker, D.; Royle, L.; de Sousa, A. S.; Williams, J. A. G.; Woord, M. Non-Radiative Deactivation of the Excited States of Europium, Terbium and Ytterbium Complexes by Proximate Energy-Matched OH, NH and CH Oscillators: an Improved Luminescence Method for Establishing Solution Hydration States. J. Chem. Soc. Perkin Trans. 2 1999, 2, 493-504.

(17) Supkowski, R. M.; Horrocks, Jr., W. D. On the Determination of the Number of Water Molecules, $q$, Coordinated to Europium(III) Ions in Solution from Luminescence Decay Lifetimes. Inorganica Chim. Acta 2002, 340, 44-48.

(18) Aime, S.; Barge, A.; Botta, M.; Howard, J. A. J.; Kataky, R.; Lowe, M. P.; Moloney, J. M.; Parker, D.; de Sousa, A. S. Dependence of the Relaxivity and Luminescence of Gadolinium 
and Europium Amino-Acid Complexes on Hydrogencarbonate and pH. Chem. Commun. 1999, 2, 1047-1048.

(19) Botta, M.; Aime, S.; Barge, A.; Bobba, G.; Dickins, R. S.; Parker, D.; Terreno, E. Ternary Complexes between Cationic GdIII Chelates and Anionic Metabolites in Aqueous Solution: An NMR Relaxometric Study. Chem. Eur. J. 2003, 9, 2102-2109.

(20) Aime, S.; Gianolio, E.; Terreno, E.; Giovenzana, G. B.; Pagliarin, R.; Sisti, M.; Palmisano, G.; Botta, M.; Lowe, M. P.; Parker, D. Ternary Gd(III)L-HSA Adducts: Evidence for the Replacement of Inner-Sphere Water Molecules by Coordinating Groups of the Protein. Implications for the Design of Contrast Agents for MRI. J. Biol. Inorg. Chem. 2000, 5, 488497.

(21) Aime, S.; Terreno, E.; Botta, M.; Bruce, J. I.; Parker, D.; Mainero, V. Modulation of the Water Exchange Rates in [Gd-DO3A] Complex by Formation of Ternary Complexes with Carboxylate Ligands. Chem. Commun. 2001, 1, 115-116.

(22) Mato-Iglesias, M.; Roca-Sabio, A.; Pálinkás, Z.; Esteban-Gomez, D.; Platas-Iglesias, C.; Tóth, É.; De Blas, A.; Rodríguez-Blas, T. Complexes Based on a 1,7-Diaza-12-Crown-4 Platform Containing Picolinate Pendants: A New Structural Entry for the Design of Magnetic Resonance Imaging Contrast. Inorg. Chem. 2008, 47, 7840-7851.

(23) de Sousa, P. L.; Livramento, J. B.; Helm, L.; Merbach, A. E.; Même, W.; Doan, B. T.; Beloeil, J. C.; Prata, M. I. M.; Santos, A. C.; Geraldes, C. F. G.; Tóth, É. In Vivo MRI Assessment of a Novel Gd ${ }^{\mathrm{III}}$-Based Contrast Agent Designed for High Magnetic Field Applications. Contrast Media Mol. Imaging 2008, 3,78-85.

(24) Regueiro-Figueroa, M.; Platas-Iglesias, C. Toward the Prediction of Water Exchange Rates in MagneticResonance Imaging Contrast Agents: A Density Functional Theory Study. $J$. Phys. Chem. A 2015, 119, 6436-6445.

(25) Bader, R. F. W.; Carroll, M. T.; Cheeseman, J. R.; Chang, C. Properties of Atoms in Molecules: Atomic Volumes. J. Am. Chem. Soc. 1987, 109, 7968-7979.

(26) (a) Borel, A.; Helm, L.; Merbach, A. E. Molecular Dynamics Simulations of MRI-Relevant Gd ${ }^{\mathrm{III}}$ Chelates: Direct Access to Outer-Sphere Relaxivity. Chem. Eur. J. 2001, 7, 600-610. (b) Lopez-Vidal, E. M.; Regueiro-Figueroa, M.; Garcías, M. D.; Platas-Iglesias, C.; Peinador, C.; Quintela, J. M. Probing Electrostatic Potential by NMR with the Use of a Paramagnetic Lanthanide(III) Chelate. Inorg. Chem. 2012, 51, 4429-4431.

(27) Powell, D. H.; Dhubhghaill, O. M. N.; Pubanz, D.; Helm, L.; Lebedev, Y. S.; Schlaepfer, W. Merbach, A. E. Structural and Dynamic Parameters Obtained from ${ }^{17} \mathrm{O}$ NMR, EPR, and NMRD Studies of Monomeric and Dimeric $\mathrm{Gd}^{3+}$ Complexes of Interest in Magnetic Resonance Imaging: An Integrated and Theoretically Self-Consistent Approach. J. Am. Chem. Soc. 1996, 118, 9333-9346. 
(28) Esteban-Gómez, D.; de Blas, A.; Rodríguez-Blas, T.; Helm, L.; Platas-Iglesias, C. Hyperfine Coupling Constants on Inner-Sphere Water Molecules of Gd ${ }^{\mathrm{III}}$-Based MRI Contrast Agents. ChemPhysChem 2012, 13, 3640-3650.

(29) Fries, P. H.; Belorizky, E. J. Electronic Relaxation of Paramagnetic Metal Ions and NMR Relaxivity in Solution: Critical Analysis of Various Approaches and Application to a Gd(III)-Based Contrast Agent. Chem. Phys. 2005, 123, 124510.

(30) Helm, L.; Merbach, A. E. Inorganic and Bioinorganic Solvent Exchange Mechanisms. Chem. Rev. 2005, 105, 1923-1959.

(31) Baranyai, Z.; Botta, M.; Fekete, M.; Giovenzana, G. B.; Negri, R.; Tei, L.; Platas-Iglesias, C. Ligand Denticity Leading to Improved Thermodynamic and Kinetic Stability of the $\mathrm{Gd}^{3+}$ Complex: The Strange Case of OBETA. Chem. Eur. J. 2012, 18, 7680-7685.

(32) Sun, Y.-Y.; Yi, J.; Lu, X.; Zhang, Z.-Q.; Xiao, B.; Fu, Y. Cu-Catalyzed Suzuki-Miyaura Reactions of Primary and Secondary Benzyl Halides with Arylboronates. Chem. Commun. 2014, 50, 11060-11062.

(33) Gans, P.; Sabatini, A.; Vacca, A. Investigation of Equilibria in Solution. Determination of Equilibrium Constants with the HYPERQUAD Suite of Programs. Talanta 1996, 43, 17391753.

(34) Alderighi, L.; Gans, P.; Ienco, A.; Peters, D.; Sabatini, A.; Vacca, A. Hyperquad Simulation and Speciation (HySS): a Utility Program for the Investigation of Equilibria Involving Soluble and Partially Soluble Species. Coord. Chem. Rev. 1999, 184, 311-318.

(35) Tao, J. M.; Perdew, J. P.; Staroverov, V. N.; Scuseria, G. E. Climbing the Density Functional Ladder: Nonempirical Meta-Generalized Gradient Approximation Designed for Molecules and Solids. Phys. Rev. Lett. 2003, 91, 146401.

(36) Gaussian 09, Revision E.01, Frisch, M. J.; Trucks, G. W.; Schlegel, H. B.; Scuseria, G. E.; Robb, M. A.; Cheeseman, J. R.; Scalmani, G.; Barone, V.; Mennucci, B.; Petersson, G. A.; Nakatsuji, H.; Caricato, M.; Li, X.; Hratchian, H. P.; Izmaylov, A. F.; Bloino, J.; Zheng, G.; Sonnenberg, J. L.; Hada, M.; Ehara, M.; Toyota, K.; Fukuda, R.; Hasegawa, J.; Ishida, M.; Nakajima, T.; Honda, Y.; Kitao, O.; Nakai, H.; Vreven, T.; Montgomery, J. A., Jr.; Peralta, J. E.; Ogliaro, F.; Bearpark, M.; Heyd, J. J.; Brothers, E.; Kudin, K. N.; Staroverov, V. N.; Kobayashi, R.; Normand, J.; Raghavachari, K.; Rendell, A.; Burant, J. C.; Iyengar, S. S.; Tomasi, J.; Cossi, M.; Rega, N.; Millam, J. M.; Klene, M.; Knox, J. E.; Cross, J. B.; Bakken, V.; Adamo, C.; Jaramillo, J.; Gomperts, R.; Stratmann, R. E.; Yazyev, O.; Austin, A. J.; Cammi, R.; Pomelli, C.; Ochterski, J. W.; Martin, R. L.; Morokuma, K.; Zakrzewski, V. G.; Voth, G. A.; Salvador, P.; Dannenberg, J. J.; Dapprich, S.; Daniels, A. D.; Farkas, Ö.; Foresman, J. B.; Ortiz, J. V.; Cioslowski, J.; Fox, D. J. Gaussian, Inc., Wallingford CT, 2009. 
(37) Dolg, M.; Stoll, H.; Savin, A.; Preuss, H. Energy-Adjusted Pseudopotentials for the Rare Earth Elements. Theor. Chim. Acta 1989, 75, 173-194.

(38) Tomasi, J.; Mennucci, B.; Cammi, R. Quantum Mechanical Continuum Solvation Models. Chem. Rev. 2005, 105, 2999-3093.

(39) Rappe, A. K.; Casewit, C. J.; Colwell, K. S.; Goddard III, W. A.; Skiff, W. M. UFF, a Full Periodic Table Force Field for Molecular Mechanics and Molecular Dynamics Simulations. J. Am. Chem. Soc. 1992, 114, 10024-10035.

(40) (a) Barysz, M.; Sadlej, A. J. Two-Component Methods of Relativistic Quantum Chemistry: from the Douglas-Kroll Approximation to the Exact Two-Component Formalism. J. Mol. Struct. (Theochem) 2001, 573, 181-200. (b) Reiher, M. Douglas-Kroll-Hess Theory: a Relativistic Electrons-Only Theory for Chemistry. Theor. Chem. Acc. 2006, 116, 241-252.

(41) Neese, F. The ORCA program system, Wiley Interdiscip. Rev.: Comput. Mol. Sci. 2012, 2 , $73-78$

(42) Aravena, D.; Neese, F.; Panzatis, D. A. Improved Segmented All-Electron Relativistically Contracted Basis Sets for the Lanthanides. J. Chem. Theory Comput. 2016, 12, 1148-1156.

(43) (a) Weigend, F.; Ahlrichs, R. Balanced Basis Sets of Split Valence, Triple Zeta Valence and Quadruple Zeta Valence Quality for H to Rn: Design and Assessment of Accuracy. Phys. Chem. Chem. Phys. 2005, 7, 3297-3305. (b) Pantazis, D. A.; Chen, X.-Y.; Landis, C. R.; Neese, F. All-Electron Scalar Relativistic Basis Sets for Third-Row Transition Metal Atoms. J. Chem. Theory Comput. 2008, 4, 908-919.

(44) (a) Neese, F.; Wennmohs, F.; Hansen, A.; Becker, U. Efficient, Approximate and Parallel Hartree-Fock and Hybrid DFT Calculations. A 'Chain-of-Spheres' Algorithm for the Hartree-Fock Exchange. Chem. Phys. 2009, 356, 98-109. (b) Izsak, R.; Neese, F. An Overlap Fitted Chain of Spheres Exchange Method. J. Chem. Phys. 2011, 135, 144105. (c) Petrenko, T.; Kossmann, S.; Neese, F. Efficient Time-Dependent Density Functional Theory Approximations for Hybrid Density Functionals: Analytical Gradients and Parallelization. $J$. Chem. Phys. 2011, 134, 054116. (d) Kossmann, S.; Neese, F. Comparison of Two Efficient Approximate Hartree-Fock Approaches. Chem. Phys. Lett. 2009, 481, 240-243.

(45) Stoychev, G. L.; Auer, A. A.; Neese, F. Automatic Generation of Auxiliary Basis Sets. J. Chem. Theory Comput. 2017, 13, 554-562.

(46) Marenich, A. V.; Cramer, C. J.; Truhlar, D. G. Universal Solvation Model Based on Solute Electron Density and on a Continuum Model of the Solvent Defined by the Bulk Dielectric Constant and Atomic Surface Tensions. J. Phys. Chem. B 2009, 113, 6378-6396. 
TOC GRAPHIC

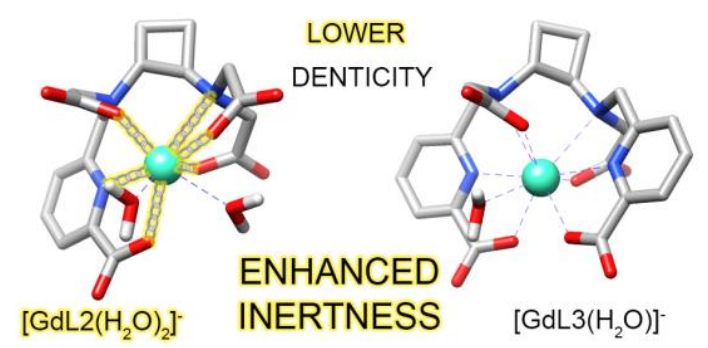

\section{SYNOPSIS}

Highly rigid ligands (L2) $)^{4-}$ and (L3) ${ }^{4-}$ form bishydrated and monohydrated $\mathrm{Gd}^{3+}$ complexes, respectively, with comparable thermodynamic stability. In contrast, $\left[\mathrm{Gd}(\mathrm{L} 3)\left(\mathrm{H}_{2} \mathrm{O}\right)\right]^{-}$is considerably more labile than $\left[\mathrm{Gd}(\mathrm{L} 2)\left(\mathrm{H}_{2} \mathrm{O}\right)_{2}\right]^{-}$providing an uncommon example in which lowering ligand denticity results in a remarkable increase in kinetic inertness. Thanks to the presence of two inner sphere water molecules, $[\mathrm{Gd}(\mathrm{L} 2)]^{-}$is endowed with high relaxivity, which is retained in the presence of large excess of endogenous anions, excluding ternary complex formation. 